\title{
National Culture and Corporate Cash Holdings Around the World
}

\begin{abstract}
In this paper we examine whether national culture can explain the variation in corporate cash holdings around the world. We also examine whether there is an association between the individualism-collectivism dimension within the United States (at a state level) and corporate cash holdings. We establish three major findings. First, employing Hofstede's $(1980,2001)$ cultural dimensions proxied by individualism and uncertainty avoidance for 27,801 firms across 41 countries spanning the 1989-2009 period, we demonstrate that corporate cash holdings are negatively affected by individualism and positively affected by uncertainty avoidance. Second, employing the Vandello and Cohen (1999) individualism-collectivism dimension we show that firms in individualistic states in the United States hold less cash than firms in collectivistic states. Third, we show that individualism is positively and significantly related to the firm's capital expenditures, acquisitions, and repurchases and negatively related to payout and uncertainty avoidance is negatively related to the firm's capital expenditures, acquisitions, payout, and repurchases. We document this within the United States (at the state level) and internationally. Our findings are robust to a variety of methodological approaches, alternative specifications of cash holdings, alternative measures of national culture and a battery of control variables. Taken together, this is the first major study to show that differences in national culture and culture within the United States can explain the variation in cash holdings at a state level and internationally.
\end{abstract}

Keywords: Individualism, Uncertainty avoidance, Autonomy, Cash holdings, National Culture

JEL Classification: G12, G14, G15 


\section{National Culture and Corporate Cash Holdings Around the World}

\section{Introduction}

In this paper, we examine whether national culture explains the variation in corporate cash holdings around the world. We also examine whether there is an association between the individualism-collectivism dimension within the United States (at a state level) and corporate cash holdings. Following, extant literature in behavioral finance, we employ Hofstede's $(1980,2001)$ cultural dimensions to investigate whether the degree of a country's individualism and uncertainty avoidance can explain the variation in corporate cash holdings. Our paper is positioned at the intersection of two strands of research in the literature. The first strand of research focuses on corporate cash holdings and the second strand focuses on the cross-cultural psychology and behavioral finance.

Prior studies on the cash holding literature have identified at least seven motives for firms to hold cash. The seven motives are (a) the transaction motive (Baumol (1952), Meltzer (1963), Miller and Orr (1966), and Mulligan (1997)); (b) the precautionary motive (Keynes (1936), Myers and Majluf (1984), Opler et al. (1999), and Bates, Kahle, and Stulz (2009)); (c) the agency motive (Jensen (1986), Dittmar, Mahrt-Smith, and Servaes (2003), Mikkelson and Partch (2003), Pinkowitz, Stulz, and Williamson (2006), Dittmar and Mahrt-Smith (2007), and Harford, Mansi, and Maxwell (2008)); (d) the financial constraint motive (Almeida, Campello, and Weisbach (2004), Khurana, Martin, and Pereira (2006), Han and Qiu (2007) and Denis and Sibilkov (2010)]; (e) the tax motive [Foley, Hartzell, Titman, and Twite (2007)); (f) the diversification motive (Duchin (2010)); and (g) the product market competitiveness motive (Haushalter, Klasa, and Maxwell (2007), Fresard (2010), Schroth and Szalay (2010)). In a more recent paper, Dittmar and Duchin (2011) document that firm level cash holding in the United States decline each year as firm's age. They show that young firms rebalance their cash holdings toward a target ratio whereas older firms 
demonstrate weaker cash rebalancing and market timing behaviours. They also note that existing models reflect the cash policies of young firms and they do a poor job in explaining the cash policies of older firms.

It is evident from the above discussion that the majority of the past research has primarily focused on the U.S. market. Three exceptions that focus on the determinants of cash holdings in an international setting are: (i) Dittmar, Mahrt-Smith and Servaes (2003); (ii) Pinkowitz, Stulz and Williamson (2006); and (iii) Kalcheva and Lins (2007). Dittmar, Mahrt-Smith, and Servaes (2003) find cross-country evidence that firms hold more cash in countries with agency problems. Pinkowitz, Stulz, and Williamson (2006) show that the value of cash holdings is less in countries with poor investor protection and Kalcheva and Lins (2007) show that when external country-level shareholder protection is weak firm values are lower when controlling managers hold more cash. They also show that when external shareholder protection is weak firm values are higher when managers pay dividends. In short, the central focus of these studies is the association between corporate governance and cash holdings and they confirm that corporate cash holdings tend to be large under poor governance system and cash holdings are valued less in countries with weaker investor protection.

We provide a new and novel angle by examining whether national culture affects the variation in international corporate cash holdings. To our knowledge, our study is the first to examine the association between national culture (proxied by individualism and uncertainty avoidance) and cash holdings and argues that national culture is an important determinant of corporate cash holdings. By studying a diverse group of 41 countries with similar and dissimilar governance structures, similar and different stages of financial development we show that cash holding decisions cannot be effectively studied without considering national culture as one of its main determinants. Our study is also the first to investigate the association between culture within the United States (at a state level) and corporate cash holdings. 
The second strand of research relevant to our paper focuses on the cross-cultural psychology and behavioral finance. In this strand studies have examined the impact of cultural values on economic outcomes. For instance, Guiso, Sapienza and Zingales (2009a) show that perceptions rooted in culture are important but omitted determinants of economic exchange. Botazzi, Da Rin and Hellmann (2010) demonstrate that the Eurobarometer measure of trust among nations significantly affects investment decisions. Giannetti and Yafeh (2011) show that cultural differences increase the loan spread, limit the loan size and reduce the investment of participant banks and Ahern, Daminelli and Fracassi (2011) document that cultural differences have substantial impact on multiple aspects of cross-border mergers. Studies have also documented that cultural differences affect capital structure (Chui, Lloyd and Kwok 2002), stock market participation (Guiso, Sapienza and Zingales, 2009b), firm risk taking (Griffin, Li, Yue and Zhao 2009), stock price momentum (Chui, Titman and Wei, 2010), dividend payout policy (Shao, Kwok and Guedhami, 2010), growth and innovation (Gorodnichenko and Roland 2010) and earnings quality (Kanagaretnam, Yeow Lim and Lobo, 2011). ${ }^{1}$

\footnotetext{
${ }^{1}$ Chui, Lloyd and Kwok (2003) document that national culture may be a missing puzzle of capital structure determination and that it may be an important determinant in various corporate finance decisions. Ramirez and Tadesse (2007) examine the relation between national culture, the multinationality of the firm and its cash holdings. They document that cultural factors as well as the degree of multinationality of firms influence their decisions to hold cash. Chui and Kwok (2008) document that even after controlling for economic, institutional and demographic factors life insurance consumption is positively related to individualism and negatively related to power distance and masculinity and femininity. Guiso, Sapienza and Zingales (2009b) document that lack of trust can explain as to why individuals do not participate in the stock market even in the absence of other frictions. They also show that differences in trust across individuals and countries help explain why some investors invest while others do not. Shao, Kwok and Guedhami (2010) document that conservatism is positively related and mastery is negatively related to dividend payouts.
} 
Against this backdrop, we investigate the association between national culture and cash holdings by hypothesizing a negative relation between individualism and firm cash holdings and a positive relation between uncertainty avoidance and cash holdings. We hypothesize a negative relation between individualism and cash holdings as we forward that managers in individualistic cultures tend to be overconfident about the firms' future earnings ability and are more likely to engage in acquisitions and capital expenditures when they have excess cash. We hypothesize a positive relation between uncertainty avoidance and firm cash holdings as managers in high uncertainty avoiding cultures tend to dislike uncertainty and ambiguity and thus their preference is to hold cash to hedge against possible cash shortfalls in the future.

Our analysis yields some striking findings. Using data for 27,801 firms across 41 countries spanning the period $1989-2009$, we show that individualism is negatively correlated and uncertainty avoidance is positively correlated with firm cash holdings. This is only the beginning of our interesting story. Our paper is the first in the finance literature to employ the Vandello and Cohen (1999) index and show that the individualism-collectivism dimension is negatively correlated with corporate cash holdings within the United States (at a state level). We then investigate the implications of cash holdings within the United States and internationally by asking "what might firms do with cash holdings"? We show that individualism is positively and significantly related to the firm's capital expenditures, acquisitions, and repurchases and negatively related to payout and uncertainty avoidance is negatively related to the firm's capital expenditures, acquisitions, payout, and repurchases. We show this within the United States (at the state level) and internationally. In addition to establishing the above main findings we also document a negative relation between our measure of corporate life cycle (RE/TE and RE/TA) and corporate cash holdings. Our findings are robust to different econometric techniques, alternative specifications of cash holdings, alternative measures of national culture (Schwartz and GLOBE), and the inclusion of a host of country-level control variables. 
Our study contributes to the cash holdings and the cross-cultural psychology literature in three different ways. Our first contribution is we document that national culture is an important determinant of cash holdings. Specifically, we find that even after controlling for external governance factors (prior studies have focused on investor protection, shareholders rights, legal origin etc.) and a host of control variables the cultural factors, proxied by individualism and uncertainty avoidance are statistically significant and explain the variation in cash holdings around the world. This contribution integrates the literature in finance and cross-cultural psychology and provides compelling evidence that corporate finance decisions are determined not only by an objective judgment of firms' risk and returns, but also by the managers' subjective beliefs, which often hinge on manager's cultural inheritance.

Our second contribution is that we are the first to employ the Vandello and Cohen (1999) individualism-collectivism index to determine if there is an association between cash holdings and the individualism-collectivism dimension at the state level within the context of the United States. We show that firms in individualistic states within the United States have lower cash holdings than firms in collectivistic states.

Our third contribution is that prior studies have not examined the implications of cash holdings within the United States or internationally. We are the first to document that in individualistic cultures firms' attitude towards capital expenditures, acquisitions and repurchases results in their lower level of cash holdings and firms in high uncertainty avoidance cultures accumulate cash through cutting down on capital expenditures, acquisitions, repurchases and payout. Empirical results from our study clearly support the hypothesis that behavioral biases and risk preferences, as captured in national culture, determine the level of corporate cash holdings within the United States and internationally.

In addition, to the above main contributions to the cash holdings and the cross-cultural psychology literature we also contribute to the life-cycle theory literature by showing that corporate life-cycle has a significant impact on corporate cash 
policies for the markets investigated in this paper. We document a striking difference between younger and mature firms in that we find a negative relation between our measure of corporate life cycle (RE/TE and RE/TA) and corporate cash holdings. Our finding is consistent with Dittmar and Duchin (2011) who show that U.S. firms substantially decrease their cash holdings over the corporate life-cycle. Our paper is the first to document this relation between in an international setting. Our finding is also consistent with DeAngelo, DeAngelo and Stulz (2006) and DeAngelo, DeAngelo and Stulz (2010) who document that corporate life-cycle has major implications for firm's dividend and issuance policies.

Whilst our paper is similar to Dittmar and Duchin (2011) in that we study the relation between corporate life-cycle and corporate cash holdings there are three key differences between our paper and Dittmar and Duchin (2011). First, we test the relation between life-cycle theory and corporate cash holdings by employing the proxies advanced by DeAngelo, DeAngelo and Stulz (2006) while Dittmar and Duchin (2011) employ firm age as a proxy for corporate life-cycle. DeAngelo, DeAngelo and Stulz (2006) document that firms with a low proportion of retained earnings to total equity (RE/TE) tend to be in the capital infusion stage while firms with a high proportion of retained earnings to total equity (RE/TE) tend to be more mature firms with high profits. They argue that the earned / contributed capital mix is a logical proxy for the life cycle as it measures the extent to which the firm is self-financing or reliant on external capital.

The second key difference is Dittmar and Duchin (2011) show that U.S. firms substantially decrease their cash holdings over the corporate life-cycle whilst we document this relation in an international setting. The third key difference is that we show a positive relation between the spending patterns of firms and the life-cycle theory. That is, we show that mature firms tend to pay dividends and are engaged in capital expenditure activities, acquisitions and repurchases while Dittmar and Duchin 
(2011) do not address this issue. Our finding that dividends tend to be paid by mature firms are in line with DeAngelo, DeAngelo and Stulz (2006).

Taken together, we demonstrate that national culture explain the variation in cash holdings beyond the effect of governance structures documented in Dittmar, Mahrt-Smith and Servaes (2003) and Pinkowitz, Stulz and Williamson (2006).

The remainder of this paper is organized as follows. In Section II, we provide a brief review the literature and develop our testable hypotheses. Section III discusses the data, variable construction and provides descriptive statistics for the sample. Section IV reports the empirical findings of our tests of the two hypotheses. Section V discusses the robustness tests while Section VI examines the impact of national culture on investment intensity. Section VII investigates the association between the individualism-collectivism dimension within the context of the United States and corporate cash holdings while section VIII investigates the relation between the individualism-collectivism dimension and cash holdings. Section IX provides concluding remarks.

\section{Hypothesis Development}

We examine the effect of Hofstede's $(1980,2001)$ cultural variables, namely individualism and uncertainty avoidance, on firm cash holdings. ${ }^{2}$ These two cultural

\footnotetext{
${ }^{2}$ Hofstede's seminal study, "Culture's Consequences," which is based on a cross-cultural survey of IBM employees, distinguishes among four dimensions assumed to capture cross-cultural differences. The four dimensions are: individualism-collectivism, masculinity-femininity, power distance, and uncertainty avoidance. Power distance (PD) refers to the degree of inequality that exists-and that is accepted-among people with and without power. A high PD score indicates that society accepts an unequal distribution of power and people understand "their place" in the system. A low PD score indicates that power is shared and well dispersed. It also means that society members view themselves as equals. Individualism (IDV) refers to the strength of the ties people have to others within the community. A high IDV score indicates a loose connection between people. In countries with high IDV scores, there is a lack of interpersonal connection and little sharing of responsibility, beyond family and
} 
variables have been shown to have significant influence on economic outcomes (Chui, Lloyd and Kwok, 2003; Guiso, Sapienza and Zingales, 2009b; Chui, Titman and Wei, 2010; Ahern, Daminelli and Fracassi, 2010; Shao, Kwok and Guedhami, 2010; Kanagaretnam, Yeow Lim and Lobo, 2011).

\section{A. Individualism and Corporate Cash Holdings}

Individualism refers to the degree to which people tend to hold an independent rather than an interdependent self-image or sense of self-esteem (Hofstede, 2001). Cultures high on individualism emphasize individual freedom and cultures low on individualism emphasizes strong group cohesion (Griffin, Li, Yue and Zhao 2009). De Mooij and Hofstede (2010) state in individualistic cultures, one's identity is in the person. That is, people are 'l'-conscious and self-actualization is important. In collectivistic cultures, people are 'we'-conscious and their identity is based on the social system to which they belong, and avoiding loss of face is important.

People in individualistic cultures focus more on how their abilities differentiate from their peers and hence they exhibit overconfidence and self-attribution biases. Markus and Kitayama (1991) and Heine, Lehman, Markus and Kitayama (1999) argue that people in individualistic cultures tend to overestimate their own abilities. They are also more overoptimistic about the precision of their predictions (Van den Steen,

perhaps a few close friends. Societies with a low IDV scores show strong group cohesion, and there is a great deal of loyalty and respect for members of the group. Masculinity (MAS) refers to how much a society values traditional male and female roles. High MAS scores are found in countries where men are expected to be tough, to be the provider, to be assertive, and to be strong. In low-MAS societies, the roles are simply blurred. Men are allowed to be sensitive and women can work hard for professional success. Uncertainty avoidance refers to the extent to which people are uncomfortable with uncertain, unstructured, or unknown situations. Of the four dimensions, we use individualism and uncertainty avoidance, as they have been correlated with economic phenomena (Kirkman et al. 2006 and Beugelsdijk and Frijns, 2010) 
2004). Ferris, Jayaraman, and Sabherwal (2009) find that corporate managers from Christian cultures that encourage individualism generally feel that they have superior decision-making abilities and are more capable than their peers. The psychology and behavioral finance literature characterizes people acting as if they have more ability than they actually possess as overconfident (Yates, 1990; Trivers, 1991; Campbell, Goodie, and Foster, 2004). In contrast, people from collectivist cultures display higher self-monitoring which largely lessens cognitive bias from overconfidence (Biais, Hilton, Mazurier, and Pouget, 2005). The overconfidence bias associated with individualistic cultures is very similar to that widely discussed in the behavioral finance3 literature.

In addition, Markus and Kitayama (1991) and Kagitcibasi (1997) suggest that the tendency to maintain and promote self-esteem in individualistic cultures results in pervasive self-attribution bias as well as overconfidence. Several other studies also show that self-attribution bias is significantly higher in Western cultures as compared to Eastern cultures because a higher degree of individualism is associated with Western cultures while a higher degree of collectivism is associated with Eastern cultures (Fry and Gosh, 1980; Chandler, Shama, Wolf, and Planchard, 1981; Kashima and Triandis, 1986). Given this discussion, we hypothesize that the demand for and the usage of cash varies between individualistic and collectivistic managers. This is because individualistic managers are more confident about the firms' financial situations, and as a result, tend to underestimate the demand for cash than managers from collectivistic culture. On the other hand, managers in a collectivistic culture emphasize on preserving the public image. Holding a high level of cash is a signal to the public that the firm is well-managed and has good investment opportunities. Because individualistic managers stress on individual success and esteem and tend

\footnotetext{
${ }^{3}$ Several behavioral finance studies define overconfident individuals as the ones who overestimate the precision of their private information, but not of public information (Kyle and Wang, 1997; Daniel, Hirshleifer, and Subrahmanyam, 1998; Odean, 1998).
} 
to be overconfident they are more likely to engage in acquisitions and capital expenditures when they have excess cash. This discussion leads to our first hypothesis.

Hypothesis 1: Firms in individualistic culture hold less cash than firms in collectivistic culture.

\section{B. Uncertainty Avoidance and Corporate Cash Holdings}

Hofstede $(1980,2001)$ states that uncertainty avoidance measures the extent to which a culture programs its members to feel either uncomfortable or comfortable in unstructured situations, which are defined as novel, unknown, surprising, or different from usual. The main underlying dimension is individual tolerance for uncertainty (ambiguity), which in identical situations leads some individuals to feel more pressed for action than others. The term "uncertainty avoidance" was introduced in Cyert and March (1963), who state that people in uncertainty-avoiding cultures emphasize short-run reaction to short-run feedback rather than anticipation of long-run uncertainty; such people solve pressing problems rather than develop long-run strategies. The opposite holds for people with high tolerance for uncertainty. Hofstede $(1980,2001)$ further documents that people with low uncertainty avoidance often exhibit a low sense of urgency in ambiguous, surprising, or unstructured situations, whereas people in high uncertainty-avoiding culture feel more anxious in such situations, and therefore tend to take immediate action to reduce the level of ambiguity. Put simply, cultures high on uncertainty avoidance avoid ambiguous situations and prefer clear rules of conduct whereas cultures low on uncertainty avoidance enjoy novel events and value differences (Griffin, Li, Yue and Zhao 2009).

Uncertainty avoidance is linked to preferences such as rules, stability, uniformity, and especially closely related to psychological characteristics widely discussed in the behavioral finance literature such as conservatism, and risk aversion. First, 
conservatism refers to the preference for a cautious and sceptical approach to measurement as opposed to a more optimistic, laissez-faire, and risk-taking approach. In high uncertainty-avoiding cultures, individuals have a tendency to experience uneasiness and reluctance when they face with situations that change the status quo and create uncertainty. As a result, they tend to respond to such contexts with trepidation and a good deal of caution and scepticism (Hofstede, 1983). Gray (1988) shows that conservatism is most closely linked with uncertainty avoidance dimension of a culture. He suggests that in uncertainty-avoiding cultures there is a cautious approach to cope with the uncertainty of future events and therefore a higher level of conservatism is adopted for accounting measurement practices.

Complementing the study of Gray (1988), Salter and Niswander (1995) find that countries that are high in uncertainty avoidance scores are more likely to adopt a conservative approach designed to prohibit financial reporting practices that may increase firms' profits or assets. Second, uncertainty avoidance also relates to a high level of risk aversion. For example, Chui and Kwok (2008) show that people from high uncertainty-avoiding cultures have more life insurance consumption level so as to cope with future uncertainty and Beugelsdijk and Frijns (2010) find that investors from high uncertainty-avoiding cultures invest less in risky foreign assets because they have low preference for risk. We hypothesize that uncertainty avoidance has an impact on firm cash holdings. Managers from high uncertainty avoiding cultures would tend to dislike uncertainty associated with future cash flows generated by firms and thus prefer to hold more cash. On the other hand, managers with low uncertainty avoidance would tend to be more comfortable with uncertain and ambiguous situations and therefore require less cash to hedge against possible cash shortfalls in the future. This discussion leads to our second hypothesis.

Hypothesis 2: Firms in high uncertainty-avoiding culture hold more cash than firms in low uncertainty avoiding culture. 


\section{Data and Variable Construction}

This section describes the data collection process and variable construction. Data for this study are obtained from several sources. ${ }^{4}$ The Hofstede individualism index (IDV) and uncertainty-avoidance index (UAI) are obtained from the Geert Hofstede ${ }^{5}$ psychological survey of IBM employee values, conducted twice (1968 and 1972) in 72 countries. Of these 72 countries, 40 had more than 50 respondents each. The individualism index, constructed and extended by Geert Hofstede (1980, 2001), is based on country mean scores on 14 questions about IBM employee's attitudes towards their work and private lives. The higher the index of a country, the higher the individualism in the country is and people who live in high individualistic cultures are likely to be more over-optimistic and more overconfident (Titman et al. (2010)).

The uncertainty-avoidance index is derived from country mean scores or percentages on three survey questions that address rule orientation, employment stability, and stress. The higher the index of a country, the higher the

\footnotetext{
${ }^{4}$ Details can be found in Appendix 1.

${ }^{5}$ Since the Hofstede survey was conducted in the 1970s, one could argue that changes in cultural values that have occurred over the past four decades would weaken our linkage between the variation in the profitability of earnings momentum strategy and cultural values. However, the robust relation observed in our paper between IDV, UAI and the variation in the profitability of the earnings momentum strategy clearly shows that cultural values are widely shared within nations (Griffin, Li, Yue and Zhao, 2009). In addition, Chui et al. (2010) point out that the survey conducted by Hofstede is regarded as the most comprehensive and comparative both in terms of the number of countries and the number of respondents involved (see, for example, Kagitcibasi, 1997). Furthermore, many replications of Hofstede's study on different samples have proved that the country ranking in his data is still valid. In the second edition of his book Culture's Consequences (2001), Hofstede describes over 200 external comparative studies and replications that have supported his indexes. Tung and Verbeke (2010) state that despite the criticisms that have been voiced against Hofstede's work his influence on the fields of international business and management is undeniable. They report that according to Harzing's publish or perish citation index, as of June 2010 there were 54,000 citations to Hofstede's work.
} 
uncertainty-avoidance in the country is. People who live in high uncertainty-avoidance culture are more risk averse and would like to prefer safe assets rather than risky assets.

We obtain financial data for Canadian and US firms from Compustat North America and for all other countries from Compustat Global. A comprehensive list of variable, definitions and sources is provided in Appendix 1. Although the literature (see for example, Bates, Kahle and Stulz, 2009) employs several definitions of the cash ratio including (a) cash to assets, (b) cash to net assets, (c) log of cash to net assets and (d) cash to sales, we employ cash to assets as our main definition and cash to net assets and cash to sales as our alternative definitions. The results using the alternative definitions are discussed in the robustness checks section. Our main measure (cash to assets) has been employed in Opler, Pinkowitz, Stulz and Williamson (1999) and Bates, Kahle and Stulz (2009). Our alterative definitions have been employed in Opler, Pinkowitz, Stulz and Williamson (1999), Dittmar, Mahrt-Smith and Servaes (2003), and Bates, Kahle and Stulz (2009).

Following, Dittmar, Mahrt-Smith, and Servaes (2003) and Bates, Kahle and Stulz (2009) we include market-to-book ratio (MB), firm size (SIZE), net working capital to assets (NWC), cash flow to assets (CF), R\&D to sales (RND), cash flow volatility (CFV), and leverage (LEV) as control variables. Market-to-book is defined as the book value of assets minus the book value of equity plus the market value of equity divided by the book value of the assets. Bates, Kahle and Stulz (2009) state that firms with better investment opportunities value cash more and hoard more cash to reduce the risk of future financing constraints. Firm size is defined as the natural logarithm of the firm's book value of assets. Net working capital to assets is defined as the firm's working capital net of cash and cash equivalents divided by its book value of assets. Since net working capital and cash are substitutes, firms with higher net working capital are expected to hold less cash. Cash flow to assets is defined as the ratio of operating cash-flow over book assets. Bates, Kahle and Stulz (2009) state that firms 
with higher operating cash-flow accumulate more cash and that such firms have better investment opportunities. R\&D to sales (measures growth opportunities) is defined as the firm's research and development expenses divided by its sales revenue. Following, Bates, Kahle, and Stulz (2009), we set R\&D to sales (measure of growth opportunities) equal to zero if it is missing.

As R\&D to sales is another measure of investment opportunities, we expect it to be positively correlated with firm cash holdings. Cash-flow volatility is defined as the standard deviation of cash flow over the past ten years, requiring at least three years of data. We use this as one of the control variables as Bates, Kahle and Stulz (2009) state that firms with greater cash flow risk hold more precautionary cash. Leverage ratio is defined as book value of debt divided by book assets. Bates, Kahle and Stulz (2009) note that if debt is constraining firms will use cash to reduce leverage resulting in a negative relationship between cash holdings and leverage.

More recently, Dittmar and Duchin (2011) document that firms monotonically and substantially decrease their cash holdings over the corporate life-cycle. Specifically, they document that firm level cash holdings decline each year as firm's age. The two main variables of interest in the Dittmar and Duchin (2011) paper are a firm's cash holdings and age. Dittmar and Duchin (2011) define age as the number of years since the firms IPO and they obtain the age variable from COMPUSTAT. We are unable to employ the Dittmar and Duchin (2011) proxy as our focus is on international markets and Compustat Global does not have the age variable. We follow DeAngelo, DeAngelo and Stulz (2006) and employ retained earnings as a proportion of total equity (RE/TE), as our main proxy for the life-cycle theory. DeAngelo, DeAngelo and Stulz (2006) argue that firms with low retained earnings over equity are more likely to be in the early stage whereas firms with high RE/TE tend to be more mature firms. They argue that the earned / contributed capital mix is a logical proxy for life-cycle as it measures the extent to which a firm is self-financing or reliant on external capital. Thus, we employ retained earnings as a proportion of total equity (RE/TE) as our main 
measure and retained earnings as a proportion of total assets (RE/TA) as our alternate proxy.

Although financial information on Compustat Global is available from 1987 we commence from 1989 as stock prices required to calculate the market-to-book ratio are available only from 1989. To be included in our analysis, a firm must have non-missing value for all the variables. Following, Bates, Kahle, and Stulz (2009)), we drop financial firms with SIC code 6000-6999 and utility firms with SIC code 4900-4999 as firms in these industries may hold cash for noneconomic reasons (e.g., capital requirements or regulation), which may distort the analysis if included. To mitigate the effect of outliers, we winsorize cash to assets, market-to-book ratio, firm size, net working capital to assets, R\&D to sales, cash-flow volatility, leverage ratio, and retained earnings to total equity at their $1^{\text {st }}$ and $99^{\text {th }}$ percentiles. We also require each country to have at least 100 observations. We commence with an initial sample of 36,987 firms from 102 countries and after applying the above mentioned filtering rules our final sample consist of 27,801 firms from 41 countries.

In Figure 1 we plot the individualism and uncertainty avoidance indices for our sample and in Table 1 we present the summary statistics of the variables across countries. All numbers with the exception of number of observations and firms are country or sample medians. The table shows that the U.S., Japan and the UK are the countries with the largest representation in the sample. The median value of our key variable, firm cash holdings is shown in Column (3). The column suggests a large cross-country variation in the ratio of cash to assets. The overall median is 0.107 across 41 countries. However, some countries have median cash holdings of less than 0.05 (New Zealand and Portugal), while some countries have median cash holdings in excess of 0.15 (Hong Kong).

\section{[Insert Table 1 and Figure 1about here]}

We also report large variation in the individualism and uncertainty avoidance indices in columns (4) and (5). The individualism index ranges from 14 for Indonesia 
and Pakistan to 91 for the U.S., while the uncertainty-avoidance index ranges from 8 for Singapore to 112 for Greece. Table 1 also reports country medians for the control variables. The sample median for the market-to-book ratio is 1.279 while that of firm size is 6.398. The sample firms also have median net working capital to assets of 0.040 and median cash-flow to assets of 0.019 . The median value for $R \& D$ to sales is zero for most of the countries and for the overall sample as the majority of firms in our sample have little or no R\&D expenditure. Further, the median cash flow volatility is 0.038 and the median leverage ratio is 0.191 . The median value for retained earnings to total equity is 0.33 .

Table 2 presents the correlation matrix of the variables. The first column shows that the level of firm cash holdings is negatively correlated with individualism suggesting that firms in individualistic cultures are likely to hold less cash. Cash holdings are positively correlated with uncertainty-avoidance, suggesting that firms in high uncertainty avoidance cultures hold more cash. The level of cash holdings is positively correlated to the firm's market-to-book ratio, R\&D to sales and cash-flow volatility, while negatively correlated to firm size, net working capital to assets, cash-flow to assets, leverage ratio, and retained earnings to total equity. The correlation coefficient between individualism and uncertainty-avoidance index is -0.186 suggesting a negative but relatively low correlation between the two cultural factors.

\section{[Insert Table 2 about here]}

\section{The Impact of National Culture on Corporate Cash Holdings}

In this section we present the results of our regression analysis on the relationship between cash holdings and national culture. Our base line model is similar to that of Dittmar et al. (2003). Their model has the measures of capital market development which we introduce later as part of robustness checks. Their dependent variable is the log of cash and equivalents divided by net assets, but we use this as the alternative 
specification in the robustness checks section. We follow Bates, Kahle and Stulz (2009) and measure the cash ratio as cash and marketable securities divided by total assets.

$$
\mathrm{CASH}_{i, t}=\alpha+\beta_{1} \cdot I D V_{i, t}+\beta_{2} \cdot U A I_{i, t}+\gamma \cdot \text { Controls }_{i, t}+\text { Ind }_{j, t}+Y_{t}+\varepsilon_{i, t}
$$

where $i$ indexes firm, $t$ indexes year, $j$ indexes industry, Ind is industry fixed-effect, defined at the two-digit SIC code level, $Y r$ is year fixed-effect, and $\varepsilon$ is the error term.

The dependent variable is firm cash holdings (CASH) and the independent variables of interest are the two cultural factors, individualism (IDV) and uncertainty avoidance (UAI). We predict a negative sign for $\beta_{1}$ and a positive sign for $\beta_{2}$. Control variables include market-to-book ratio (MB), firm size (SIZE), net working capital to assets (NWC), cash-flow to assets (CF), R\&D to sales (RND), cash flow volatility (CFV), leverage ratio (LEV), and retained earnings to equity (RE/TE). The regression is performed by pooled ordinary least squares (pooled OLS), with the t-statistics computed using standard errors robust to both clustering at the firm level and heteroskedasticity. The regression results are presented in Table 3. Column (1) presents the results without control variables while Column (2) presents the results with a full set of control variables. The results reported in Column (1) shows that firm cash holdings is negatively related to individualism and positively related to uncertainty avoidance. The coefficients are statistically significant at the one-percent level.

In Column (2), we include the control variables into our regression model. It is important to note that the coefficients retain their sign and statistical significance. The magnitude of the coefficient indicates that a one unit change in individualism leads to $0.036 \%$ reduction in firm cash holdings. Other things being equal, moving from the lowest (14) to the highest (91) individualism index will result in a reduction in cash 
holdings by 0.0277 (or $2.77 \%$ of the book value of assets). This finding is consistent with our first hypothesis that firms in individualistic culture hold less cash than firms in collectivistic culture. Furthermore, one unit change in the uncertainty avoidance index leads to $0.062 \%$ change in firm cash holdings. Other things being equal, moving from the lowest (8) to the highest (112) uncertainty avoidance index will result in an increase in cash holdings by 0.0645 (or $6.45 \%$ of the book value of assets).

\section{[Insert Table 3 about here]}

Since a large proportion (42\%) of our sample firms come from the United States the regression results may be distorted due to bias in sample selection. To address this potential problem, we drop the United States from our sample. We repeat the same analysis on this sample and present the regression results in Columns (3) and (4) of Table 3. Our findings show that even after excluding the United States from the analysis, individualism and uncertainty-avoidance are still negatively and positively associated with firm cash holdings. The coefficients retain their statistical and economic significance indicating that the results are not sample specific. Our results for the control variables are generally consistent with prior literature (e.g., Opler et al. (1999), Dittmar, Mahrt-Smith, and Servaes (2003), Bates, Kahle, and Stulz (2009) and Dittmar and Duchin (2011)). Specifically, we show that firm cash holdings is positively related to market-to-book ratio, cash-flow to assets, $R \& D$ to sales and cash-flow volatility, while negatively related to firm size, net working capital to assets, leverage ratio, and retained earnings to total equity.

\section{Robustness tests}

In this section, we perform various tests to check the robustness of our findings. We employ different econometric techniques, alternative specifications of cash holdings, alternative measures of national culture, inclusion of a host of country-level control variables and an alternative proxy for life-cycle.

\section{[Insert Table 4 about here]}




\section{A. The Fama-MacBeth Approach}

In this subsection, we adopt the Fama-MacBeth regression technique and rerun the regression specification in Equation (1) each year from 1989 to 2009 and then take the time-series average of the coefficient estimates from the annual regressions. The methodology is meant to minimize time-series variation while capturing cross-sectional variation. The regression results are presented in Columns (1) and (6) of Table 4. Column (1) displays the results for the full sample and shows that individualism is negatively associated while uncertainty avoidance is positively associated with firm cash holdings. Both coefficients are significant at the one-percent level. Column (6) displays the results for the sample excluding the U.S. and it is important to note that the results are identical to the main results reported in Column (1).

\section{B. Alternative Definitions of Cash Holdings}

We employ alternative definitions of firm cash holdings and regress the alternative definitions on national culture. We use the ratio of the firm's cash and cash equivalents divided by its book value of assets net of cash and cash equivalents and the ratio of the firm's cash and cash equivalents divided by its sales revenue as alternative definitions of firm cash holdings. The regression results are presented in Columns (2), (3), (7) and (8) of Table 4 . We show that the findings for the alternative definitions are largely identical to those obtained using the main definition.

\section{Alternative Measures of National Culture - GLOBE Project Research Program and Schwartz Cultural Dimensions}

Although, Merritt (2000) and Hofstede (2001) document that Hofstede's cultural indices are stable over time, we follow Chui et al (2010) to investigate whether our results are affected by the possible changes in the IDV scores of Hofstede (1980, 2001). We collect cultural values from the GLOBE (Global Leadership and 
Organizational Behavior Effectiveness) project and rerun our main model. The GLOBE project is a network of 170 social scientists and management scholars focusing on culture and leadership in 61 nations. The GLOBE project classifies national culture into nine dimensions. ${ }^{6}$ They are: (1) Uncertainty Avoidance, (2) Power Distance, (3) Institutional Collectivism (4) In-Group Collectivism (5) Gender Egalitarianism, (6) Assertiveness, (7) Future Orientation, (8) Performance Orientation, and (9) Humane Orientation (See, House et al. 2002). House et al (2002) document that the first six culture dimensions had their origins in the dimensions of culture identified by Hofstede (1980). Specifically, the first three scales (uncertainty avoidance, power distance and institutional collectivism) are intended to reflect the same constructs as Hofstede's dimensions labelled Uncertainty Avoidance, Power Distance, and Individualism. We collect the country scores (for all 41 countries in our sample) on the GLOBE's institutional collectivism and uncertainty avoidance dimensions from Javidan and House (2001), Ashkanasy, Trevor-Roberts and

\footnotetext{
${ }^{6}$ House et al (2002) define the nine dimensions as follows. Uncertainty avoidance is defined as the extent to which members of an organization or society strive to avoid uncertainty by reliance on social norms, rituals, and bureaucratic practices to alleviate the unpredictability of future events. Power Distance is defined as the degree to which members of an organization or society expect and agree that power should be unequally shared. Institutional collectivism reflects the degree to which organizational and societal institutional practices encourage and reward collective distribution of resources and collective action. In-Group collectivism reflects the degree to which individuals express pride, loyalty and cohesiveness in their organizations or families. Gender Egalitarianism is the extent to which an organization or a society minimizes gender role differences. Assertiveness is the degree to which individuals in organizations or societies are assertive, confrontational, and aggressive in social relationships. Future Orientation is the degree to which individuals in organizations or societies engage in future-oriented behaviors such as planning, investing in the future, and delaying gratification. Performance Orientation refers to the extent to which an organization or society encourages and rewards group members for performance improvement and excellence and lastly, Humane Orientation is the degree to which individuals in organizations or societies encourage and reward individuals for being fair, altruistic, friendly, generous, caring, and kind to others.
} 
Earnshaw (2002), Bakacsi, Sandor, Andras and Viktor (2002), Gupta, Suri, Javidan and Chhokar (2002), Jesuino (2002), Kabasakal and Bodur (2002) and Szabo, Hartog, Weibler and Wunderer (2002). ${ }^{7}$ Ashkanasy, Trevor-Roberts and Earnshaw (2002) examine cultural values in the Anglo cluster, Bakacsi et al. (2002) examine cultural practices in the Eastern European cluster, Gupta et al (2002) examine cultural values in the Southern Asia cluster, Jesuino (2002) examines cultural values in the Latin Europe cluster, Kabasakal and Bodur (2002) examine the Arabic cluster and Szabo et al (2002) examine the Germanic Europe cluster.

The GLOBE's institutional collectivism index, reflects the degree of collectivism in each country, i.e., the higher a country's score in this index, the higher is its degree of collectivism. Following, Chui et al. (2010), and to be consistent with Hofstede's individualism index, we create a new variable IDV ${ }_{\text {GLOBE }}$ which is defined as the GLOBE's institutional collectivism index multiplied by -1 . We report the results in Columns (4) and (9) of Table 4. The results reported are consistent with the main findings in Table 3. That is, we find the estimated IDV ${ }_{\text {GLOBE }}$ coefficient is negative and significant for the sample with and without the United States. As far as uncertainty avoidance is concerned our results in Table 4 are similar to the findings in Table 3. That is, UAI ${ }_{\text {GLOBE }}$ is positive and significant for the full sample and the sample excluding the U.S. In short, our findings indicate that cash holdings is negatively related to individualism and positively related to uncertainty avoidance irrespective of whether we employ the Hofstede or the GLOBE Project Index.

\section{Schwartz's Cultural Dimensions}

Schwartz (1994) classifies national culture into six value types and condenses these values into three dimensions (Chui et al. 2002). Schwartz's indices are from survey

\footnotetext{
7 The GLOBE Project indices (Institutional Collectivism and Uncertainty Avoidance) and the results are available from the authors upon request.
} 
responses of over 25,000 elementary school teachers and university students in 44 countries. The six values are conservatism ${ }^{8}$, intellectual and affective autonomy, hierarchy, mastery, egalitarian compromise and harmony. These six values are condensed into three broad dimensions. The three dimensions are: Autonomy vs. Conservatism, Hierarchy vs. Egalitarianism and Mastery vs. Harmony. Prior research has employed Schwartz's (1994) dimensions of cultural values. Chui et al. (2002) document that firms in a country with high conservatism scores are expected to use less debt in their capital structures and managers in countries with high mastery scores employ less debt financing. That is, they show that firms in countries with high scores on mastery and embeddedness have lower debt ratios. Li et al. (2011) show that the mastery and embeddedness dimensions of Schwartz (1994) has significant explanatory power in the leverage decisions of foreign joint ventures in China. Shao et al. (2010) show that conservatism is positively related and mastery negatively to dividend payouts around the world. Ahern et al. (2011) document that trust, hierarchy and individualism have major impact on many aspects of cross-border mergers.

Following prior research we employ the Schwartz (1994) cultural dimensions as our second alternative cultural measure. We find a negative relation between autonomy $^{9}$ and corporate cash holdings. Since, conservatism focuses on interdependent social relations where security, conformity and tradition are valued and autonomy focuses on the individual as an autonomous entity to pursue his or her own

\footnotetext{
${ }^{8}$ Chui et al. (2002) identify the properties of the six types. Conservatism includes values that are important in close-knit relationships in which the interests of the individual are not viewed as distinct from those of the group. Intellectual and affective autonomy are likely to be important in a society that views the individual as an autonomous entity entitled to pursue his or her interests. Hierarchy stresses the legitimacy of hierarchical role and resource allocation. Mastery emphasizes on active mastery of the social environment through self-assertion. Egalitarian compromise emphasizes the transcendence of selfish interests and finally harmony emphasizes harmony with nature (Chui et al. 2002, 101-102).

9 The Schwartz (1994) cultural values and the results are available from the authors upon request.
} 
goals the autonomy versus conservatism dimension of Schwartz (1994) is similar to the individualism-collectivism dimension of Hofstede $(1980,2001)$. In short, our results obtained using the two alternative cultural measures (Schwartz and GLOBE) are consistent with our main findings where we employ the Hofstede dimension.

[Insert Figure 2 about here]

\section{E. Additional Country-level Controls}

We include five country level characteristics as control variables. Our first country level characteristic is investor protection index (PROTN) as suggested by LLSV (1998). Dittmar, Mahrt-Smith and Servaes (2003) employ the LLSV (1998) shareholders rights measure and show that firms in the high shareholders rights group have lower median cash to net assets than countries with low shareholder rights. Their findings are in line with the argument that firm hold more cash when the shareholder protection is weak. LLSV (1998) construct the anti-director rights index (an index aggregating the shareholder rights) for 49 countries. This index is formed by adding 1 when: (1) the country allows shareholders to mail their proxy vote; (2) shareholders are not required to deposit their shares prior to the General Shareholder's Meeting; (3) cumulative voting is allowed; (4) an oppressed minority mechanism is in place; or (5) when the minimum percentage of share capital that entitles a shareholder to call for an extraordinary shareholder's meeting is less than or equal to $10 \%$. The index ranges from 0 to 5 .

Our second country level characteristic is common law versus civil law (COMCIV). We use common law versus civil law as a control variable as LLSV (1998) document that laws differ significantly around the world and in particular, countries whose legal rules originate in the common law tradition tend to protect investors significantly better than the countries whose laws originate in the civil law and the French civil law tradition. Dittmar, Mahrt-Smith and Servaes (2003) investigate whether their results firms in the high shareholders rights group have lower median cash to net assets than 
countries with low shareholder rights hold when they include a common law dummy in their regression model. They find that the coefficient on the common law dummy to be negative and significant indicating that firms in common law countries hold less cash than in civil law countries.

Our third country level characteristic is corruption index (CRPTN), which measures the level of corruption in a country. We use this variable as Pinkowitz, Stulz and Williamson (2006) report that when corruption is high firms will need to pay off officials and thus managers will need to hold high levels of cash. Our fourth country level characteristic is economic freedom (EF), which is an indicator of how a country's policies rank in terms of providing economic freedom. It is a composite of ten indicators ranking policies in the areas of trade, government finances, government interventions, monetary policy, capital flows and foreign investment, banking and finance, wages and prices, property rights, regulation, and black market activity. Higher scores indicate polices more conducive to competition and economic freedom. We follow Beck et al. (2005) and Ramirez and Tadesse (2007) in employing this control variable. Ramirez and Tadesse (2007) state that firms in economies with higher levels of economic freedom will require lower levels of liquid assets.

Our final country level characteristic is bank- vs. market-based financial system (BNKMKT). It is an indicator variable equal to one if a country has bank-based financial system and zero if a country has market-based financial system. We follow the Demirguc-Kunt and Levine (1999) classification of market-based or bank-based financial structures. They construct a conglomerate index of financial structure based on size, activity and efficiency and create ratios of banking sector development and stock market development. They classify countries with larger ratios of banking sector development to capital market development as bank-based and countries where the conglomerate ratio of banking sector development to stock market development is below the mean as market-based. This classification of Demirguc-Kunt and Levine (1999) produces two categories of countries - bank-based and market-based. We 
employ this classification as our final control variable as Pinkowitz and Williamson (2001) show that the level of cash holdings is higher in Japan than in Germany or the United States. They attribute this to the difference in corporate governance between Japan and the United States in that in the United States, capital markets are the main monitor ${ }^{10}$, while in Japan the main bank is the primary monitor of the firm.

Columns (5) and (10) of Table 4 present the regression results with control variables for country characteristics. Column (5) shows that the coefficient of the individualism index is negative and highly significant and the coefficient of the uncertainty is positive but insignificant at conventional levels. Almost identical results are reported for the sample excluding the U.S. in Column (10). The results for additional country level control variables are consistent with prior studies (e.g., Pinkowitz and Williamson (2001), Dittmar et al. (2003) and Pinkowitz et al. (2006)). For instance, we show that the coefficient for bank-based versus market-based financial systems is positive and significant which implies that firms in bank-based financial systems hold more cash than firms in market-based financial systems. Our finding is consistent with Pinkowitz and Williamson (2001) who document that Japanese firms hold more cash than firms in the United States and Germany and attribute this finding to the Japanese system of governance which is characterized by large banks having monopoly power.

We also find that firm cash holdings are negatively associated with investor protection, suggesting that firms in countries with better investor protection hold less cash. This finding is consistent with Dittmar et al. (2003) who document that firms in countries with the lowest level of shareholder protection hold almost $25 \%$ more cash than firms in countries with the highest level of shareholder protection. Further, firms in common law countries and in countries with higher corruption scores tend to hold

10 Demirguc-Kunt and Levine (1999, p.1) state that in bank-based financial systems banks play a leading role in mobilizing savings, allocating capital, overseeing the investment decisions of corporate managers and in providing risk management vehicles. They also state that in market-based financial systems securities markets share center stage with banks in terms of getting society's savings to firms, exerting corporate control and easing risk management. 
less cash, while firms in countries with more economic freedom and have bank-based financial system tend to hold more cash. Our finding that firms in common law countries and in countries with higher corruption scores tend to hold less cash is consistent with prior studies by Dittmar et al. (2003) who document that firms in common law countries hold $35 \%$ less cash than firms in civil law countries and Ramirez and Tadesse (2009) who document that when corruption is high firms will hold lower level of liquid assets to avoid temptation to pay off functionaries. Our finding that firms in countries with more economic freedom and bank-based financial system tend to hold more cash is consistent with Ramirez and Tadesse (2009) and Pinkowitz and Williamson (2001) respectively.

\section{F. Alternative proxy for life-cycle}

Following, DeAngelo, DeAngelo and Stulz (2006) we employed retained earnings as a proportion of total equity (RE/TE) as our main proxy for the life-cycle stage of a firm. The results for the main proxy are reported in Tables 3 - 5 and Table 7 . We also employ retained earnings as a proportion of total assets (RE/TA) as our second proxy and our results are identical to the main proxy results reported in Tables $3-5$ and Table 7.

\section{Impact of National Culture on Investment Intensity and Payout}

So far we have shown that firms tend to hold less (more) cash in countries with high (low) individualism index or low (high) uncertainty-avoidance index. The next obvious question is - what might firms do with cash holdings? In this section, we answer this question by examining firms' capital investments, acquisitions, dividend payout and repurchases decisions. Our study is the first to examine this association in an international setting and we provide a cultural explanation for the decisions made by managers around the world. Hackbarth (2004), Malmendier and Tate (2005), Ben-David, Graham, and Harvey (2007), and Gervais, Heaton and Odean (2007) 
have shown that firms that have overconfident executives might invest more intensively than other firms as they perceive the investment projects to be less risky than they really are. We test our hypothesis that firms in individualistic culture will hold less cash and engage in more acquisition and capital expenditure activities than firms in collectivistic culture by regressing investment intensity variables on national culture, proxied by individualism and uncertainty avoidance.

Our investment intensity variables are capital expenditures (CAPE), which we define as capital expenditures scaled by assets, and acquisitions (ACQ) which we define as the firm's acquisitions scaled by assets. Our payout variables are dividends (DIV), which we define as the firm's dividend payments scaled by assets, and repurchases (REP), which we define as the firm's repurchases scaled by assets. We introduce the same set of control variables in the cash holdings regression into the investment intensity and payout regressions. Our model takes the following form:

$$
\begin{aligned}
& \text { CAPE / ACQ / DIV / REP } P_{i, t}=\alpha+\beta_{1} \cdot I D V_{i, t} \\
& +\beta_{2} \cdot U A I_{i, t}+\gamma \cdot \text { Controls }_{i, t}+\text { Ind }_{j, t}+Y r_{t}+\varepsilon_{i, t}
\end{aligned}
$$

where, Ind is industry fixed-effect, defined at the two-digit SIC code level, $\mathrm{Yr}$ is year fixed-effect, and $\varepsilon$ is the error term. The regression is performed by pooled OLS, with the t-statistics computed using standard errors robust to both clustering at the firm level and heteroskedasticity. The results are presented in Table 5. Columns 1, 2 and 4 of Table 5 show that individualism is positively and significantly related to the firm's capital expenditures, acquisitions repurchases. Since individualism is employed as a proxy for overconfidence and self-attribution bias it is not surprising to note that firms in individualistic cultures expand their operations aggressively through capital expenditures and acquisitions. As far as repurchases are concerned we argue that overconfident managers are more likely to view their stock as undervalued and thus they tend to repurchase to time the market.

Our results in column 3 show a negative but significant relationship between individualism and dividend payout. This finding is consistent with Gervais, Heaton and 
Odean (2007) and Ben-David, Graham and Harvey (2007) who document that managerial overconfidence can affect payout policy. Gervais, Heaton and Odean (2007) find that overconfident managers believe that the available investment opportunities are less risky than they really are and thus overestimate their net present value. Hackbarth (2004) shows that to finance these investments managers end up diverting funds from what would have been paid out to shareholders as dividends. In short, prior research shows that overconfident managers have a lower propensity to payout dividends. Evidence from the cross-cultural psychology literature also points in this direction. For instance, Kanagaretnam et al. (2011) find that in highly individualistic cultures managers would adopt a low dividend payout and retain more cash in the firm as higher cash holdings will enable the managers to make their own decisions when investment opportunities arise. They also show that firms in mastery countries have lower dividend payouts and that mastery shareholders are more tolerant of managers retaining high cash as they trust the manager's ability and this trust offsets the shareholders concerns about agency problems to a certain extent.

The findings for uncertainty avoidance are reported in columns (1) - (4) of Table 5. We show that uncertainty avoidance is negatively related to the firm's capital expenditures, acquisitions, dividend, and repurchase decisions. As expected, the coefficients for the two investment intensity variables (capital expenditures and acquisitions) and the two payout policy variables (repurchases and dividends) are negative and significant at the one-percent level. This implies that firms in high uncertainty avoidance cultures accumulate cash through cutting down on capital expenditures, acquisitions, repurchases and dividend payouts. In columns (5) - (8) we report the results for the sample excluding U.S. firms and our results for the sample excluding the U.S. are identical to the full sample.

[Insert Table 5 about here] 


\section{Collectivism Index and Cash Holdings in the United States}

Although the culture of the United States is individualistic (Hofstede (1980) and Triandis (1994)), Vandello and Cohen (1999) argue that regions of the United States exhibit measurable variation on this dimension. They state that by studying the intra-nation variation one may learn more about the individualism-collectivism dimension in general. To test their predictions, Vandello and Cohen (1999) create an eight-item index ranking states in the U.S. in terms of individualist versus collectivistic tendencies. The first three items of their eight-item index related to family structure and living arrangements and the rest to social, political, religious and economic practices. In their eight-item index higher scores reflect greater collectivism and lower scores reflect greater individualism. Vandello and Cohen (1999) aggregate the 50 states into nine ${ }^{11}$ cultural regions.

In this section we ask whether there is an association between the individualism-collectivism dimension within the context of the United States (at a state level) and corporate cash holdings. Prior research on the individualism-collectivism dimension has involved comparing Asian economies with the United States or European countries. Our paper is the first to compare the individualism-collectivism dimension both at a country level (41 markets investigated in this paper) and solely within the context of the US. In Table 6, we report the summary statistics of our state level sample and in Table 7 we report the regression results of cash holdings at the state level on the collectivism index of Vandello and Cohen (1999). In Table 6 all

\footnotetext{
11 The nine regions are: Confederate (Deep) South (South Carolina, Mississippi, Florida, Alabama, Georgia, Louisiana, Texas, Tennessee, Arkansas, Virginia and North Carolina); Peripheral South (Delaware, Maryland, West Virginia, Kentucky, Missouri and Oklahoma); Northeast (Maine, New Hampshire, Vermont, Massachusetts, Connecticut, Rhode Island and Pennsylvania); New York and New Jersey; Midwest and Great Lakes (Ohio, Michigan, Wisconsin, Indiana, Illinois, lowa and Minnesota); Mountain West and Great Plains (Montana, Wyoming, Colorado, Idaho, Washington, Oregon, Alaska, North Dakota, South Dakota, Nebraska and Kansas); Southwest (New Mexico, Arizona, Nevada and California); Utah and Hawaii.
} 
numbers with the exception of number of observations and firms are state or sample medians. The table shows that California, Texas and New York are the states with the largest representation in the sample. The median of our key variable, firm cash holdings, is shown in Column (3). The column suggests a large state level variation in the ratio of cash to assets. The overall median is 0.099 across the 50 states. However, some states have median cash holdings of less than 0.05 (Alaska, Arkansas, lowa, Kansas, Kentucky, Louisiana, Mississippi, Missouri), while some states have median cash holdings in excess of 0.20 (California, Maine and Washington).

We also report large variation in the collectivism index in column (4) of Table 6. The collectivism index ranges from 31 for Montana to 91 for Hawaii. Table 6 also reports sample medians for the control variables. The sample median for the market-to-book ratio is 1.491 while that of firm size is 4.760 . The sample firms also have median net working capital to assets of 0.069 and median cash flow to assets of 0.017. The median value for R\&D to sales is zero for most of the states and for the overall sample as the majority of firms in our sample have little or no R\&D expenditure. The median cash flow volatility is 0.074 , the median leverage ratio is 0.173 , and the median retained earnings to total equity is 0.214 . The regression results reported in Table 7 show a negative relationship between cash holdings and individualism (IDV STATE). Although Vandello and Cohen (1999) create the collectivism index we multiply it by -1 to obtain the individualism index. We show that the coefficient (IDV $\left.V_{\text {STATE }}\right)$ is negative and statistically significant. Our results clearly establish the link between the individualism-collectivism index of Vandello and Cohen (1999) and cash holdings at the state level. Overall, our results provide compelling evidence that firms in individualistic states hold less cash than firms in collectivistic states.

[Insert Tables 6 and 7 about here] 


\section{Impact of Individualism-Collectivism Dimension on Investment Intensity and Payout}

In the previous section we documented a negative relationship between individualism at a state level and corporate cash holdings. In this section we explore in depth as to what might individualistic managers in the U.S. do with cash holdings? To answer this question we examine the association between firms' capital investments, acquisitions, dividend payout and repurchases decisions and corporate cash holdings Our study is the first to examine this association at a state-level in the U.S. setting. Our hypothesis is that firms in individualistic states within the U.S. will hold less cash and engage in more capital expenditure activities and acquisitions than firms in collectivistic states and we test our hypothesis by regressing investment intensity variables on the Vandello and Cohen (1999) collectivism index. Our first investment intensity variable is capital expenditures intensity (CAPE), which we define as capital expenditures scaled by assets. Our second investment intensity variable is acquisitions intensity (ACQ) which we define as the firm's acquisitions scaled by assets. Our payout variables are dividends (DIV), which we define as the firm's dividend payments scaled by assets, and repurchases (REP), which we define as the firm's repurchases scaled by assets.

We report the regression results in Table 8 . As far as the two investment intensity variables are concerned we show that the coefficient for CAPE and ACQ is positive and highly significant. This finding implies that firms in individualistic states expand their operations through capital expenditures and acquisitions. As far as the payout variables are concerned we find that the coefficient for repurchases (REP) is positive and significant while the coefficient for dividend payout (DIV) is negative and insignificant. The positive relationship between individualism and repurchases indicate that overconfident managers are of the view that their firms' are undervalued and thus they engage in repurchase activities. Our findings of a positive but insignificant relationship between individualism and payout is consistent with 
Hackbarth (2004) and Gervais, Heaton and Odean (2005) who document that to finance investment projects managers typically divert funds that otherwise would have been paid to shareholders as dividends. Our findings are also consistent with Ben-David et al. (2007) who show that firms with overconfident CFOs are expected to have a lower propensity to payout dividends and repurchase shares. In short, Ben-David et al. (2007) state that managerial overconfidence can affect payout policy. Taken together, our findings reported in Table 8 (U.S. state level sample) are consistent with our findings for our international sample reported in Table 5.

\section{[Insert Table 8 about here]}

\section{Conclusions}

This study examines whether national culture can explain the variation in corporate cash holdings around the world. The study also examines the association between cash holdings and the individualism-collectivism dimension of Vandello and Cohen (1999) at a state level in the United States. We argue that the demand for and the usage of cash varies between managers in individualistic and collectivistic cultures. We document that managers in individualistic cultures are more confident about their firms' prospects, and as a result, tend to underestimate the demand for cash than managers from collectivistic cultures. Managers from collectivistic cultures emphasize on preserving the public image and hence holding high levels of cash is a signal to the public that the firm is well-managed and has good investment opportunities. Thus, we hypothesize a negative relationship between individualism and firm cash holdings. As far as uncertainty avoidance is concerned we hypothesize a positive relationship between uncertainty avoidance and firm cash holdings as managers from high uncertainty avoiding cultures tend to dislike uncertainty and ambiguity and hence their preference is to hold cash. 
Our analysis yield some striking findings. Using comprehensive data for 27,801 firms across 41 countries spanning the period 1989-2009, we find that individualism is significantly negatively correlated with firm cash holdings and uncertainty avoidance is positively correlated with firm cash holdings. Our findings also indicate that firms in individualistic states within the United States hold less cash than firms in collectivistic states. We go a step further and show that for the 41 markets investigated in this paper individualism is positively and significantly related to the firm's capital expenditures, acquisitions, and repurchases and negatively related to payout and uncertainty avoidance is negatively related to the firm's capital expenditures, acquisitions, payout, and repurchases. We report similar findings at the state level within the United States. Our findings are robust to a variety of econometric approaches, alternative specifications of cash holdings, alternative measures of national culture and a battery of control variables and thus provide strong support for the importance of cultural effect in determining firm cash holdings. In sum, our study is the first major study to show that national culture and culture within the United States affect corporate financial decisions. 


\section{References}

Ahern, K. R.; D. Daminelli; and C. Fracassi. "Lost in Translation? The Effect of Cultural Values on Mergers Around the World." Ross School of Business Research Paper (2011).

Almeida, H.; M. Campello; and M. S. Weisbach. "The cash flow sensitivity of cash." Journal of Finance, 59 (2004)., 1777-1804.

Ashkanasy, N. M.; E. Trevor-Roberts; and L. Earnshaw.. "The Anglo Cluster: legacy of the British empire." Journal of World Business, 37 (2002), 28-39.

Bakacsi, G.; T. Sandor; K. Andras; and I. Viktor. "Eastern european cluster: tradition and transition." Journal of World Business (2002).

Bates, T. W.; K. M.Kahle; and R. M. Stulz. "Why do U.S. firms hold so much more cash than they used to?" Journal of Finance 64 (2009), 1985-2021.

Baumol, W. J. "The transactions demand for cash: An inventory theoretic approach." Quarterly Journal of Economics, 66 (1952), 545-556.

Ben-David, I.; J.R.Graham; and C.R. Harvey. "Managerial overconfidence and corporate policies." Working paper. Duke University (2007).

Ben-David, I., and D. Roulstone. "Limited arbitrage, mispricing, and corporate transactions." Working Paper. University of Chicago, Graduate School of Business (2005).

Beugelsdijk, S., and B. Frijins. "A cultural explanation of the foreign bias in international asset allocation." Journal of Banking and Finance, 34 (2010), 2121-2131.

Biais, B.; D.Hilton; K. Mazurier; and S. Pouget. "Judgmental overconfidence, self-monitoring, and trading performance in an experimental financial market." Review of Economic Studies, 72 (2005), 287-312. 
Bottazzi, L.; M. Da Rin; and T. Hellmann. "The importance of trust for investment: Evidence from venture capital." Working paper. Universita Bocconi (2010).

Campbell, W. K.; A. S. Goodie; and J. D. Foster. "Narcissim, confidence, and risk attitude." Journal of Behavioral Decision Making, 17 (2004), 297-311.

Chan, K.; V. Corvig; and L. Ng. "What determines the domestic bias and foreign bias? Evidence from mutual fund equity allocations worldwide." Journal of Finance 60 (2005), 1495-1534.

Chandler, T. A.; D. D. Shama; F. M. Wolf; and S. K. Planchard. "Multi-attributional causality for social affiliation across five cross-national samples." Journal of Psychology, 107 (1981), 219-229.

Choi, I.; J.A. Choi; and A. Norenzayan. "Culture and Decisions." Blackwell Handbook of Judgment and Decision Making. Edited by Derek J. Koehler and Nigel Harvey. Blackwell Publishing (2009).

Chui, A. C. W.; A. E. Lloyd; and C. C. Kwok. "The Determination of Capital Structure: Is National Culture a Missing Puzzle?" Journal of International Business Studies, 33 (2002), 99-127.

Chui, A. C. W., and C. C. Kwok. "National culture and life insurance consumption." Journal of International Business Studies, 39 (2008), 88-101.

Chui, A. C. W.; S.Titman; and K. Wei. Individualism and momentum around the world. Journal of Finance, 65 (2010), 361-392.

Cyert , R.M., and J.G. Marsh. "A behavioral theory of the firm." Englewood Cliffs, NJ: Prentice-Hall (1963).

De Mooij, M., and G. Hofstede. "The Hofstede Model: Applications to global branding and advertising strategy and research." International Journal of Advertising, 29 (2010), 85-110. 
Daniel, K.; D. Hirshleifer; and A. Subrahmanyam. "Investor psychology and security market under- and overreactions." Journal of Finance, 53 (1998), 1839-1885.

Demirguc-Kunt, A., and R. Levine. "Bank-Based and Market-Based Financial System: Cross-Country Comparisons." Working Paper. The World Bank and University of Minnesota (1999).

Denis, D., and V. Sibilkov. "Financial Constraints, Investment and the Value of Cash Holdings". Review of Financial Studies, 23 (2010), 247-269.

Dittmar, A., and J. Mahrt-Smith. "Corporate governance and the value of cash holdings." Journal of Financial Economics, 83 (2007), 599-634.

Dittmar, A.; J. Mahrt-Smith; and H. Servaes. "International corporate governance and corporate cash holdings." Journal of Financial and Quantitative Analysis, 38 (2003), 111-133.

Dittmar, A., and R. Duchin. "The Dynamics of Cash”. Working Paper. The Ross School of Business, University of Michigan (2011).

Duchin, R. "Cash holdings and corporate diversification." Journal of Finance, 65 (2010), 955-992.

Ferris, S. P.; N.Jayaraman; and S. Sabherwal. "CEO overconfidence and international merger and acquisition activity." Working paper (2009).

Foley, C.F.; J. Hartzell; S.Titman; and G.Twite. "Why do firms hold so much cash? A tax-based explanation." Journal of Financial Economics, 86 (2007), 579-607.

Fresard, L. "Financial Strength and Product Market Behaviour: The Real Effects of Corporate Cash Holdings." Journal of Finance, 65 (2010), 1097-1122. 
Fry, P. S., and R.Ghosh. "Attributions of success and failure: comparison of cultural differences between Asian and Caucasian children." Journal of Cross-Cultural Psychology, 11 (1980), 343-363.

Gervais, S.; J. B. Heaton; and T. Odean. "Overconfidence, investment policy, and manager welfare." Working Paper (2007).

Giannetti, M., and Y. Yafeh. "Do cultural differences between contracting parties matter? Evidence from Syndicated Bank Loans." Management Science, Forthcoming (2011).

Gorodnichenko, Y., and G. Roland. "Culture, institutions and the wealth of nations". University of California, Berkley. Working paper (2010).

Gray, S. J. "Towards a theory of cultural influence on the development of accounting system internationally." Abacus, 24 (1988) 1-15.

Griffin, D. W.; K. Li; H. Yue; and L. Zhao. "Cultural Values and Corporate Risk-Taking.” Working Paper (2009).

Guiso, L.; P. Sapienza; and L. Zingales. "Cultural biases in economic exchange?” The Quarterly Journal of Economics, 124 (2009a), 1095-1131.

Guiso, L.; P. Sapienza; and L. Zingales. "Trusting the Stock Market." Journal of Finance, Forthcoming (2009b).

Gupta, V.; G. Suri; M. Javidan; and J. Chhokar. "Southern Asia Cluster: Where the old meets the new?" Journal of World Business, 37 (2002), 16-27.

Hackbarth, D. "Managerial traits and capital structure decisions." Working Paper (2004).

Haushalter, D.; S. Klasa; and W.F. Maxwell. "The influence of product market dynamics on a firm's cash holdings and hedging behaviour." Journal of Financial 
Economics, 84 (2007), 797-825.

Hirshleifer, D., and S. H.Teoh. "The Psychological Attraction Approach to Accounting and Disclosure Policy." Contemporary Accounting Research, 26 (2009), 1067-1090.

Hofstede, G. "Culture's Consequences: International Differences in Work-Related Values." Beverly Hills, CA: Sage Publication (1980).

Hofstede, G. "The cultural relativity of organizational practices and theories." Journal of International Business Studies, 14 (1983), 75-89.

Hofstede, G. "Culture's Consequences: Comparing Values, Behaviors, Institutions, and Organizations across Nations" (2nd ed.). Beverly Hills, CA: Sage Publication (2001).

House, R.; M. Javidan; P. Hanges; and P. Dorfman. "Understanding cultures and implicit leadership theories across the globe: an introduction to project GLOBE." Journal of World Business, 37 (2002), 3-10.

Javidan, M., and R.H. House. "Cultural acumen for the global manager: Lessons from Project GLOBE." Organizational Dynamics, 29 (2001), 289-305.

Jegadeesh, N, and S. Titman. "Returns to buying winners and selling losers: Implications for stock market efficiency." Journal of Finance, 48 (1993), 65-91.

Jensen, M. C. "Agency Costs of Free Cash Flow, Corporate Finance, and Takeovers." American Economic Review, 76 (1986), 323-330.

Jesuino, J.C. "Latin Europe Cluster: From South to North." Journal of World Business, 37 (2002), 81-89.

Kabasakal, K., and M. Bodur. "Arabic cluster: a bridge between East and West." 
Journal of Word Business, 37 (2002), 40-54.

Kagitcibasi, C. "Individualism and collectivism." In J. W. Berry, M. H. Segall \& C. Kagitcibasi (Eds.), Handbook of Cross-cultural Psychology. Allyn \& Bacon, Boston (1997).

Kalcheva, I., and K. V. Lins. "International Evidence on Cash Holdings and Expected Managerial Agency Problems." The Review of Financial Studies, 20 (2007), 1087-1112.

Kanagaretnam, K.; C. Y. Lim; and G. J. Lobo. "Effects of national culture on earnings quality of banks." Journal of International Business Studies, 42 (2011), 853-874.

Kashima, Y., and H. C. Triandis. "The self-serving bias in attributions as a coping strategy: a cross-cultural study." Journal of Cross-Cultural Psychology, 17 (1986), 83-97.

Keynes, J. M. "The general theory of employment, interest and money." Macmillan for the Royal Economic Society: London (1936).

Khurana, I. K.; X. Martin; and R. Pereira. "Financial development and the cash flow sensitivity of cash." Journal of Financial and Quantitative Analysis, 41 (2006), 787-807.

Kim, C.; D. C.Mauer; and A. E. Sherman. "The Determinants of Corporate Liquidity: Theory and Evidence." Journal of Financial and Quantitative Analysis, 33 (1998), 335-359.

Klasa, S.; W.F. Maxwell; and H. Ortiz-Molina. "The strategic use of corporate cash holdings in collective bargaining with labour unions." Journal of Financial Economics, 92 (2009), 421-442.

Kyle, A. S., and F. A. Wang. "Speculation duopoly with agreement to disagree: Can 
overconfidence survive the market test?" Journal of Finance, 52 (1997), 2073-2090.

La Porta, R.; F. Lopez-de-Silanes; A. Shleifer; and R.W. Vishny. "Law and Finance." Journal of Political Economy, 106 (1998), 1113-1155.

La Porta, R.; F. Lopez-De-Silanes; and A. Shleifer. "What works in securities laws?" Journal of Finance, 61 (2006), 1-32.

Malmendier, U., and G. Tate. "CEO Overconfidence and Corporate Investment." Journal of Finance, 60 (2005), 2661-2700.

Markus, H. R., and S. Kitayama. "Culture and the self: Implications for cognitions, emotion, and motivation." Psychological R-eview, 98 (1991), 224-253.

Meltzer, A. "The demand for Money: A cross-section study of business firms". Quarterly Journal of Economics, (1963), 405-422.

Merritt, A. "Culture in the cockpit: Do Hofstede's dimensions replicate?" Journal of Cross-cultural Psychology, 31 (2000), 283-301.

Mikkelson, W. H., and M. M. Partch. "Do Persistent Large Cash Reserves Hinder Performance?" Journal of Financial and Quantitative Analysis, 38 (2003), 275-294.

Miller, M. H., and D. Orr. "A model of the demand for money by firms." Quarterly Journal of Economics, 80 (1966), 413-435.

Mulligan, C. B. "Scale economies, the value of time, and the demand for money: Longitudinal evidence from firms." Journal of Political Economy, 105 (1997), 1061-1079.

Myers, S., and N. Majluf. "Corporate financing and investment decisions when firms have information the investors do not have". Journal of Financial Ecinomics, 13 (1984), 
$187-221$

Odean, T. "Do investors trade too much?" American Economic Review, 89 (1999), 1279-1298.

Opler, T.; L. Pinkowitz; R. M.Stulz; and R. Williamson. "The determinants and implications of corporate cash holdings." Journal of Financial Economics, 52 (1999), 3-46.

Pinkowitz, L.; R. M.Stulz; and R. Williamson. "Does the contribution of corporate cash holdings and dividends to firm value depend on governance? A cross-country analysis." Journal of Finance, 61 (2006), 2725-2751.

Pinkowitz, L., and R. Williamson. "Bank Power and Cash Holdings: Evidence from Japan." Review of Financial Studies, 14 (2001), 1059-1082.

Ramirez, A., and S. Tadesse. "Corpoarte cash holdings, uncertainty avoidance and multinationlity of firms." International Business Review, 18 (2009), 387-403.

Riddick, L. A., and T. M. Whited. "The corporate propensity to save." Journal of Finance, 64 (2009), 1729-1766.

Roll, R. "The hubris theory of corporate takeovers." Journal of Business, 59 (1986), 197-216.

Salter, S. B., and F. Niswander. „Cultural influence on the development of accounting systems internationally: a test of Gray's (1988) theory." Journal of International Business Studies, (1995), 379-397.

Schroth, E., and D. Szalay. "Cash Breeds Success: The role of financing constraints in patent races." Review of Finance, 14 (2010), 73-118.

Schwartz, S. H. "Beyond individualism-collectivism: New dimensions of values." In u. Kim, H. C. Triandis, C. Kagitcibasi, S. C. Choi \& G. Yoon (Eds.), Individualism and 
Collectivism: Theory, Method and Application. Newbury Park, CA: Sage (1994).

Shao, L.; C. C. Kwok; and O. Guedhami. "National culture and dividend policy." Journal of International Business Studies, 41 (2010), 1391-1414.

Stulz, R. M., and R. Williamson. "Culture, openness, and finance." Journal of Financial Economics, 70 (2003), 313-349.

Szabo, E.; D. N. D. Hartog; J. Weibler; and R. Wunderer. "The Germanic Europe cluster: where employees have a voice." Journal of World Business, 37 (2002), 55-68.

Titman, S.; K.C. John Wei; and F. Xie. "Access to Equity Markets, Corporate Investments and Stock Returns: International Evidence." Working paper. The University of Texas at Austin (2010).

Trivers, R. "Deceit and self-deception." In R. Robinson \& L. Tiger (Eds.), Man and beast revisited. Washington, DC: Smithsonian (1991).

Tung, R.R. and A. Verbeke. "Beyong Hofstede and GLOBE: Improving the quality of cross-cultural research." Journal of Internatrional Business Studies, 41 (2010), 1259-1274.

Vandello, J., and D. Cohen. "Patterns of Individualism and Collectivism Across the United States." Journal of Personality and Social Psychology, 77 (1999), 279-292.

Van den Steen, E. "Rational overoptimism (and other biases)." The American Economic Review, 94 (2004), 1141-1151.

Yates, J. F. "Judgment and decision making." NY: Prentice Hall: Englewood Cliffs (1990). 
Appendix 1

Variable, Definitions and Sources

\begin{tabular}{|c|c|c|}
\hline Variable & Source & Definition \\
\hline $\begin{array}{l}\text { Cash to Assets } \\
\text { (CASH) }\end{array}$ & Compustat & Cash and Short-term Investments / Book Assets \\
\hline $\begin{array}{l}\text { Market-to-book Ratio } \\
\text { (MB) }\end{array}$ & Compustat & (Stock Price * Shares Outstanding + Book Assets - Book Equity) / Book Assets \\
\hline $\begin{array}{l}\text { Firm Size } \\
\text { (SIZE) }\end{array}$ & Compustat & Natural logarithm of Book Assets \\
\hline $\begin{array}{l}\text { Net Working Capital to Assets } \\
\text { (NWC) }\end{array}$ & Compustat & (Working Capital - Cash and Short-term Investments) / Book Assets \\
\hline $\begin{array}{l}\text { Cash Flow to Assets } \\
\text { (CF) }\end{array}$ & Compustat & (Income before Extraordinary Items - Common Dividends) / Book Assets \\
\hline $\begin{array}{l}\text { R\&D to Sales } \\
\text { (RND) }\end{array}$ & Compustat & R\&D Expense / Sales \\
\hline $\begin{array}{l}\text { Cash Flow Volatility } \\
\text { (CFV) }\end{array}$ & Compustat & $\begin{array}{l}\text { Standard deviation of Cash Flow (CF) for the previous } 10 \text { years, requiring at least three } \\
\text { observations. }\end{array}$ \\
\hline $\begin{array}{l}\text { Leverage Ratio } \\
\text { (LEV) }\end{array}$ & Compustat & (Long-term debt + Debt in Current Liabilities) / Book Assets \\
\hline $\begin{array}{l}\text { Retained Earnings to Total Equity } \\
\text { (RE/TE) }\end{array}$ & Compustat & Retained earnings / Total Equity \\
\hline $\begin{array}{l}\text { Capital Expenditure to Assets } \\
\text { (CAPE) }\end{array}$ & Compustat & Capital Expenditures / Book Assets \\
\hline $\begin{array}{l}\text { Acquisition to Assets } \\
\text { (ACQ) }\end{array}$ & Compustat & Acquisitions Expenditure / Book Assets \\
\hline
\end{tabular}




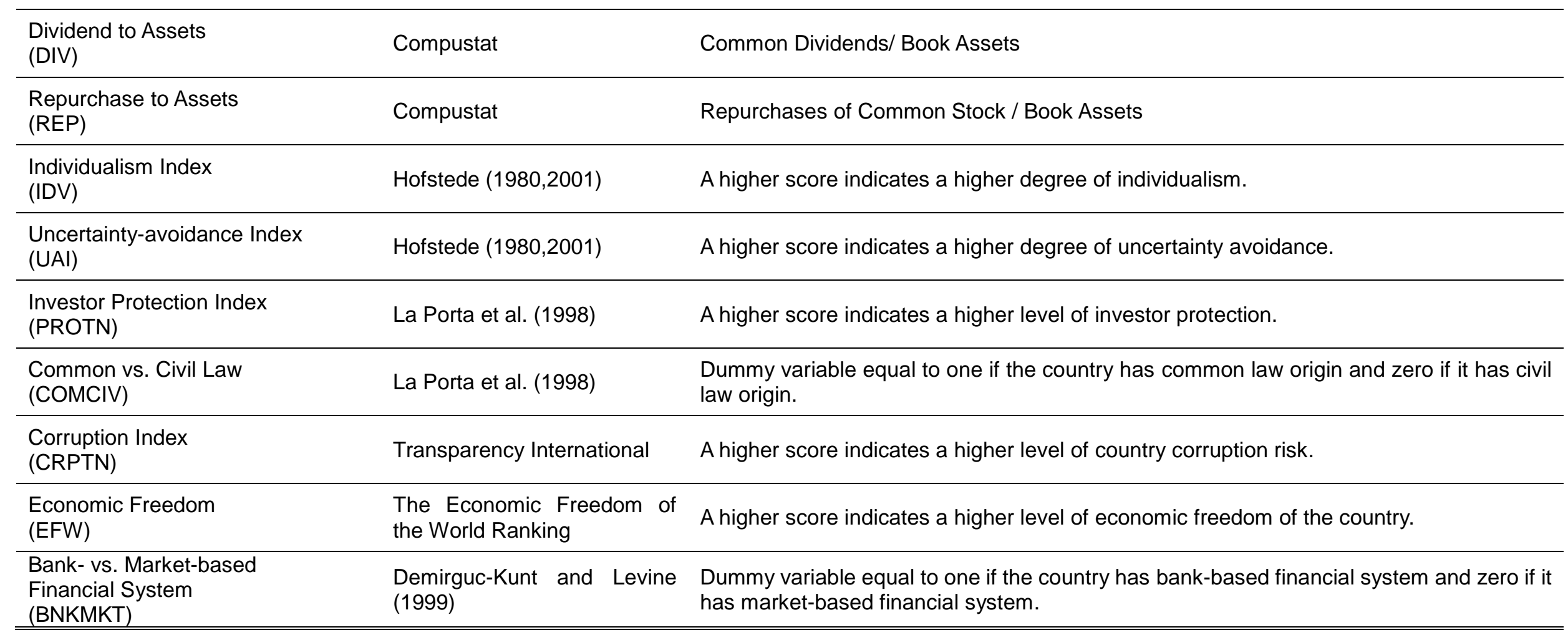


TABLE 1

Summary Statistics

Sample Period: 1989-2009

\begin{tabular}{|c|c|c|c|c|c|c|c|c|c|c|c|c|c|}
\hline Country & $\begin{array}{c}\text { \# of } \\
\text { Obs. } \\
(1)\end{array}$ & $\begin{array}{c}\# \text { of } \\
\text { Firms } \\
(2)\end{array}$ & $\begin{array}{c}\text { CASH } \\
\text { (3) }\end{array}$ & $\begin{array}{l}\text { IDV } \\
(4)\end{array}$ & $\begin{array}{l}\text { UAI } \\
(5)\end{array}$ & $\begin{array}{l}\mathrm{MB} \\
(6)\end{array}$ & $\begin{array}{c}\text { SIZE } \\
(7)\end{array}$ & $\begin{array}{l}\text { NWC } \\
(8)\end{array}$ & $\begin{array}{l}\text { CF } \\
(9)\end{array}$ & $\begin{array}{l}\text { RND } \\
(10)\end{array}$ & $\begin{array}{l}\text { CFV } \\
(11)\end{array}$ & $\begin{array}{l}\text { LEV } \\
(12)\end{array}$ & $\begin{array}{c}\text { RE/TE } \\
(13)\end{array}$ \\
\hline Australia & 4,700 & 731 & 0.052 & 90 & 51 & 1.340 & 3.207 & 0.022 & 0.019 & 0.000 & 0.026 & 0.192 & 0.208 \\
\hline Austria & 660 & 96 & 0.071 & 55 & 70 & 1.068 & 4.427 & 0.071 & 0.018 & 0.000 & 0.018 & 0.234 & 0.197 \\
\hline Belgium & 450 & 97 & 0.073 & 75 & 94 & 1.174 & 4.734 & 0.037 & 0.029 & 0.000 & 0.019 & 0.206 & 0.075 \\
\hline Brazil & 642 & 179 & 0.130 & 38 & 76 & 1.323 & 5.173 & 0.028 & 0.030 & 0.000 & 0.024 & 0.221 & 0.243 \\
\hline Canada & 3,356 & 505 & 0.093 & 80 & 48 & 1.443 & 4.546 & 0.001 & -0.007 & 0.000 & 0.080 & 0.154 & 0.042 \\
\hline Chile & 177 & 59 & 0.051 & 23 & 86 & 1.337 & 4.773 & 0.065 & 0.039 & 0.000 & 0.018 & 0.227 & 0.482 \\
\hline China & 9,232 & 1,700 & 0.139 & 20 & 30 & 1.655 & 3.689 & -0.063 & 0.023 & 0.000 & 0.033 & 0.222 & 0.151 \\
\hline Denmark & 1,210 & 149 & 0.095 & 74 & 23 & 1.125 & 3.319 & 0.069 & 0.030 & 0.000 & 0.028 & 0.244 & 0.574 \\
\hline Finland & 1,242 & 144 & 0.080 & 63 & 59 & 1.142 & 4.686 & 0.072 & 0.019 & 0.006 & 0.033 & 0.239 & 0.428 \\
\hline France & 1,840 & 505 & 0.107 & 71 & 86 & 1.223 & 3.364 & 0.036 & 0.024 & 0.000 & 0.014 & 0.200 & 0.089 \\
\hline Germany & 4,198 & 613 & 0.069 & 67 & 65 & 1.175 & 4.405 & 0.143 & 0.016 & 0.000 & 0.023 & 0.182 & 0.194 \\
\hline Greece & 623 & 126 & 0.073 & 35 & 112 & 1.294 & 2.989 & 0.067 & 0.026 & 0.000 & 0.017 & 0.273 & 0.078 \\
\hline Hong Kong & 5,020 & 844 & 0.166 & 25 & 29 & 1.026 & 4.129 & 0.011 & 0.031 & 0.000 & 0.032 & 0.141 & 0.416 \\
\hline India & 4,891 & 1,141 & 0.052 & 48 & 40 & 1.182 & 3.318 & 0.100 & 0.050 & 0.000 & 0.022 & 0.267 & 0.569 \\
\hline Indonesia & 1,089 & 205 & 0.095 & 14 & 48 & 1.058 & 3.903 & 0.030 & 0.026 & 0.000 & 0.048 & 0.305 & 0.313 \\
\hline Ireland & 613 & 65 & 0.098 & 70 & 35 & 1.234 & 3.982 & 0.029 & 0.038 & 0.000 & 0.028 & 0.248 & 0.412 \\
\hline Israel & 258 & 92 & 0.118 & 54 & 81 & 1.532 & 4.526 & 0.021 & 0.017 & 0.000 & 0.020 & 0.310 & 0.391 \\
\hline Italy & 1,100 & 229 & 0.089 & 76 & 75 & 1.050 & 5.144 & 0.048 & 0.015 & 0.000 & 0.018 & 0.225 & 0.057 \\
\hline Japan & 39,095 & 3,563 & 0.139 & 46 & 92 & 1.069 & 5.617 & 0.007 & 0.011 & 0.001 & 0.020 & 0.213 & 0.519 \\
\hline Malaysia & 5,957 & 858 & 0.084 & 26 & 36 & 1.066 & 2.633 & 0.054 & 0.028 & 0.000 & 0.030 & 0.173 & 0.309 \\
\hline Mexico & 186 & 61 & 0.079 & 30 & 82 & 1.094 & 6.587 & 0.028 & 0.043 & 0.000 & 0.021 & 0.148 & 0.705 \\
\hline Netherlands & 1,696 & 200 & 0.055 & 80 & 53 & 1.292 & 4.412 & 0.070 & 0.034 & 0.000 & 0.023 & 0.203 & 0.000 \\
\hline New Zealand & 494 & 88 & 0.023 & 79 & 49 & 1.262 & 3.105 & 0.045 & 0.017 & 0.000 & 0.028 & 0.251 & 0.315 \\
\hline Nigeria & 106 & 24 & 0.100 & 20 & 54 & 1.874 & 3.788 & -0.059 & 0.037 & 0.000 & 0.014 & 0.121 & 0.572 \\
\hline
\end{tabular}




\begin{tabular}{|c|c|c|c|c|c|c|c|c|c|c|c|c|c|}
\hline Norway & 1,146 & 197 & 0.117 & 69 & 50 & 1.253 & 3.718 & -0.010 & 0.021 & 0.000 & 0.043 & 0.253 & 0.280 \\
\hline Pakistan & 617 & 124 & 0.070 & 14 & 70 & 1.190 & 2.183 & 0.008 & 0.045 & 0.000 & 0.031 & 0.213 & 0.654 \\
\hline Philippines & 455 & 104 & 0.095 & 32 & 44 & 1.041 & 2.835 & -0.011 & 0.020 & 0.000 & 0.034 & 0.193 & 0.290 \\
\hline Poland & 117 & 59 & 0.081 & 60 & 93 & 1.320 & 3.518 & 0.123 & 0.036 & 0.000 & 0.020 & 0.079 & 0.238 \\
\hline Portugal & 215 & 46 & 0.041 & 27 & 104 & 1.112 & 4.440 & -0.016 & 0.020 & 0.000 & 0.010 & 0.332 & 0.000 \\
\hline Russia & 179 & 57 & 0.036 & 39 & 95 & 0.648 & 5.597 & -0.021 & 0.049 & 0.000 & 0.027 & 0.227 & 0.709 \\
\hline Saudi Arabia & 157 & 48 & 0.073 & 38 & 68 & 2.080 & 3.397 & 0.045 & 0.035 & 0.000 & 0.023 & 0.184 & 0.374 \\
\hline Singapore & 3,215 & 564 & 0.137 & 20 & 8 & 1.111 & 3.737 & 0.027 & 0.029 & 0.000 & 0.030 & 0.161 & 0.341 \\
\hline South Africa & 1,313 & 227 & 0.103 & 65 & 49 & 1.349 & 5.457 & 0.027 & 0.050 & 0.000 & 0.028 & 0.105 & 0.600 \\
\hline South Korea & 3,928 & 676 & 0.107 & 18 & 85 & 0.894 & 4.874 & -0.034 & 0.022 & 0.000 & 0.020 & 0.284 & 0.000 \\
\hline Spain & 785 & 126 & 0.057 & 51 & 86 & 1.238 & 4.950 & 0.018 & 0.026 & 0.000 & 0.014 & 0.196 & 0.102 \\
\hline Sweden & 2,388 & 342 & 0.101 & 71 & 29 & 1.287 & 3.315 & 0.067 & 0.024 & 0.000 & 0.035 & 0.175 & 0.319 \\
\hline Switzerland & 1,741 & 201 & 0.116 & 68 & 58 & 1.185 & 4.785 & 0.083 & 0.032 & 0.000 & 0.025 & 0.215 & 0.375 \\
\hline Thailand & 965 & 260 & 0.053 & 20 & 64 & 1.129 & 2.327 & 0.022 & 0.027 & 0.000 & 0.031 & 0.271 & 0.302 \\
\hline Turkey & 278 & 76 & 0.127 & 37 & 85 & 1.360 & 4.008 & 0.068 & 0.038 & 0.000 & 0.027 & 0.121 & 0.259 \\
\hline United Kingdom & 14,171 & 1,730 & 0.072 & 89 & 35 & 1.388 & 4.154 & 0.032 & 0.031 & 0.000 & 0.038 & 0.167 & 0.469 \\
\hline United States & 88,531 & 10,690 & 0.099 & 91 & 46 & 1.491 & 4.760 & 0.069 & 0.017 & 0.000 & 0.074 & 0.173 & 0.206 \\
\hline Total & 209,036 & 27,801 & 0.107 & 89 & 46 & 1.279 & 4.582 & 0.040 & 0.019 & 0.000 & 0.038 & 0.191 & 0.330 \\
\hline
\end{tabular}

This table reports summary statistics for the 41 countries in our sample for the period 1989 to 2009 . We require each country in our sample to have both Hofstede's individualism index (IDV) and uncertainty-avoidance index (UAI). We obtain the individualism and uncertainty avoidance indices from Hofstede $(1980$, 2001). We obtain financial information from Compustat North America for Canada and the US and Compustat Global for the remaining 39 countries. All numbers with the exception of number of observations and firms are country or sample medians. CASH is defined as cash and cash equivalents divided by book value of assets. MB is defined as market value of assets divided by book value of assets. Size is the natural logarithm of book value of assets. NWC is defined as working capital net of cash and cash equivalents divided by book value of assets. CF is defined as operating cash flow divided by book value of assets. RND is defined as research and development expenses divided by sales revenue. CFV is defined as the standard deviation of CF for the previous 10 years, requiring at least three observations. LEV is defined as the book value of debt divided by book value of assets. RE/TE is defined as retained earnings as a proportion of total equity and is our main proxy for the life-cycle theory. 
TABLE 2

Correlation Matrix

Sample Period: 1989-2009

\begin{tabular}{|c|c|c|c|c|c|c|c|c|c|c|c|}
\hline & $\mathrm{CASH}$ & IDV & UAI & MB & SIZE & NWC & $\mathrm{CF}$ & RND & CFV & LEV & RE/TE \\
\hline $\mathrm{CASH}$ & 1.000 & & & & & & & & & & \\
\hline IDV & -0.066 & 1.000 & & & & & & & & & \\
\hline UAI & 0.062 & -0.186 & 1.000 & & & & & & & & \\
\hline MB & 0.223 & 0.256 & -0.167 & 1.000 & & & & & & & \\
\hline SIZE & -0.033 & -0.608 & 0.471 & -0.239 & 1.000 & & & & & & \\
\hline NWC & -0.154 & 0.197 & -0.059 & -0.067 & -0.191 & 1.000 & & & & & \\
\hline CF & -0.001 & -0.045 & -0.107 & 0.211 & 0.082 & 0.232 & 1.000 & & & & \\
\hline RND & 0.270 & 0.262 & 0.099 & 0.186 & -0.098 & 0.111 & -0.113 & 1.000 & & & \\
\hline CFV & 0.133 & 0.460 & -0.244 & 0.222 & -0.509 & 0.044 & -0.201 & 0.228 & 1.000 & & \\
\hline LEV & -0.476 & -0.079 & 0.066 & -0.176 & 0.227 & -0.225 & -0.184 & -0.203 & -0.129 & 1.000 & \\
\hline $\mathrm{RE} / \mathrm{TE}$ & -0.103 & -0.109 & 0.096 & -0.052 & 0.298 & 0.142 & 0.339 & -0.077 & -0.282 & 0.002 & 1.000 \\
\hline
\end{tabular}

This table presents the spearman correlation matrix between the variables used in the cross-country regressions. CASH is defined as cash and cash equivalents divided by book value of assets. IDV is Hofstede's individualism index and UAI is Hofstede's uncertainty avoidance index. MB is defined as market value of assets divided by book value of assets. Size is the natural logarithm of book value of assets. NWC is defined as working capital net of cash and cash equivalents divided by book value of assets. CF is defined as operating cash flow divided by book value of assets. RND is defined as research and development expenses divided by sales revenue. CFV is defined as the standard deviation of CF for the previous 10 years, requiring at least three observations. LEV is defined as the book value of debt divided by book value of assets. RE/TE is defined as retained earnings as a proportion of total equity and is our main proxy for the life-cycle theory. 
TABLE 3

Regressions of Cash Holdings on National Culture

Sample Period: 1989-2009

$\mathrm{CASH}_{i, t}=\alpha+\beta_{1} \cdot \operatorname{IDV}_{i, t}+\beta_{2} \cdot \mathrm{UAI}_{i, t}+\gamma \cdot$ Controls $_{i, t}+\operatorname{Ind}_{j, t}+\mathrm{Yr}_{t}+\varepsilon_{i, t}$

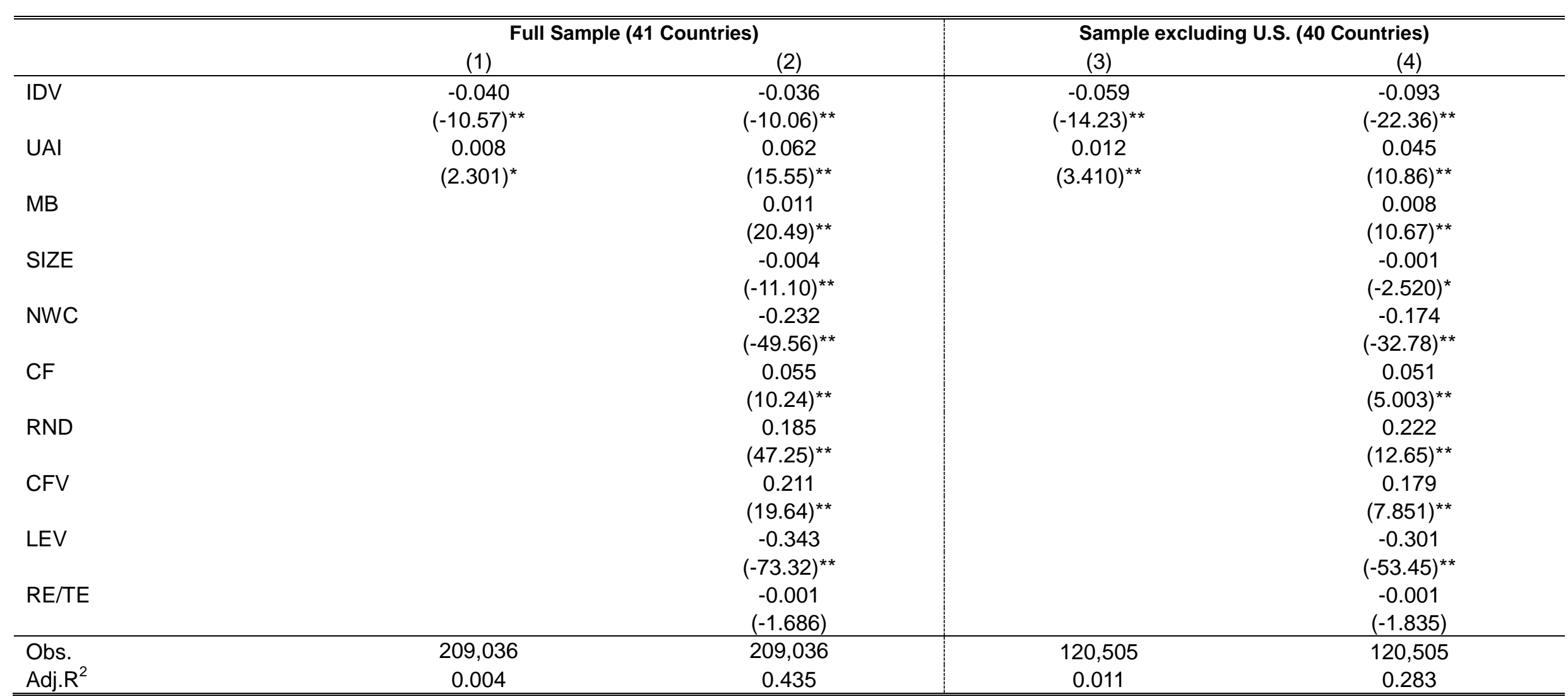


This table presents the regression results of cash holdings on national culture (proxied by individualism and uncertainty avoidance) for the 41 countries in our sample. The dependent variable is CASH, defined as cash and cash equivalents divided by book value of assets. IDV is Hofstede's individualism index. UAI is Hofstede's uncertainty avoidance index. MB is defined as market value of assets divided by book value of assets. Size is the natural logarithm of book value of assets. NWC is defined as working capital net of cash and cash equivalents divided by book value of assets. CF is defined as operating cash flow divided by book value of assets. RND is defined as research and development expenses divided by sales revenue. CFV is defined as the standard deviation of CF for the previous 10 years, requiring at least three observations. LEV is defined as the book value of debt divided by book value of assets. RE/TE is defined as retained earnings as a proportion of total equity and is our main proxy for the life-cycle theory. The regressions in Columns (2) and (4) include industry fixed-effect, defined at the two-digit SIC code level, and year fixed-effect. We run pooled OLS regressions, with t-statistics (in parentheses) computed using standard errors robust to both clustering at the firm level and heteroskedasticity. The full sample results (41 countries) are reported in Columns (1) and (2) and the results for the sample excluding the U.S. are reported in Columns (3) and (4). For ease of interpretation, we scale up the coefficients of IDV and UAI by multiplying the coefficients by $100 .{ }^{*}$ and ${ }^{* *}$ denotes significance at the $5 \%$, and $1 \%$ level respectively. 
TABLE 4

Robustness Tests

Sample Period: 1989-2009

$\mathrm{CASH}_{i, t}=\alpha+\beta_{1} \cdot I D V_{i, t}+\beta_{2} \cdot U A I_{i, t}+\gamma \cdot$ Controls $_{i, t}+\operatorname{Ind}_{j, t}+Y r_{t}+\varepsilon_{i, t}$

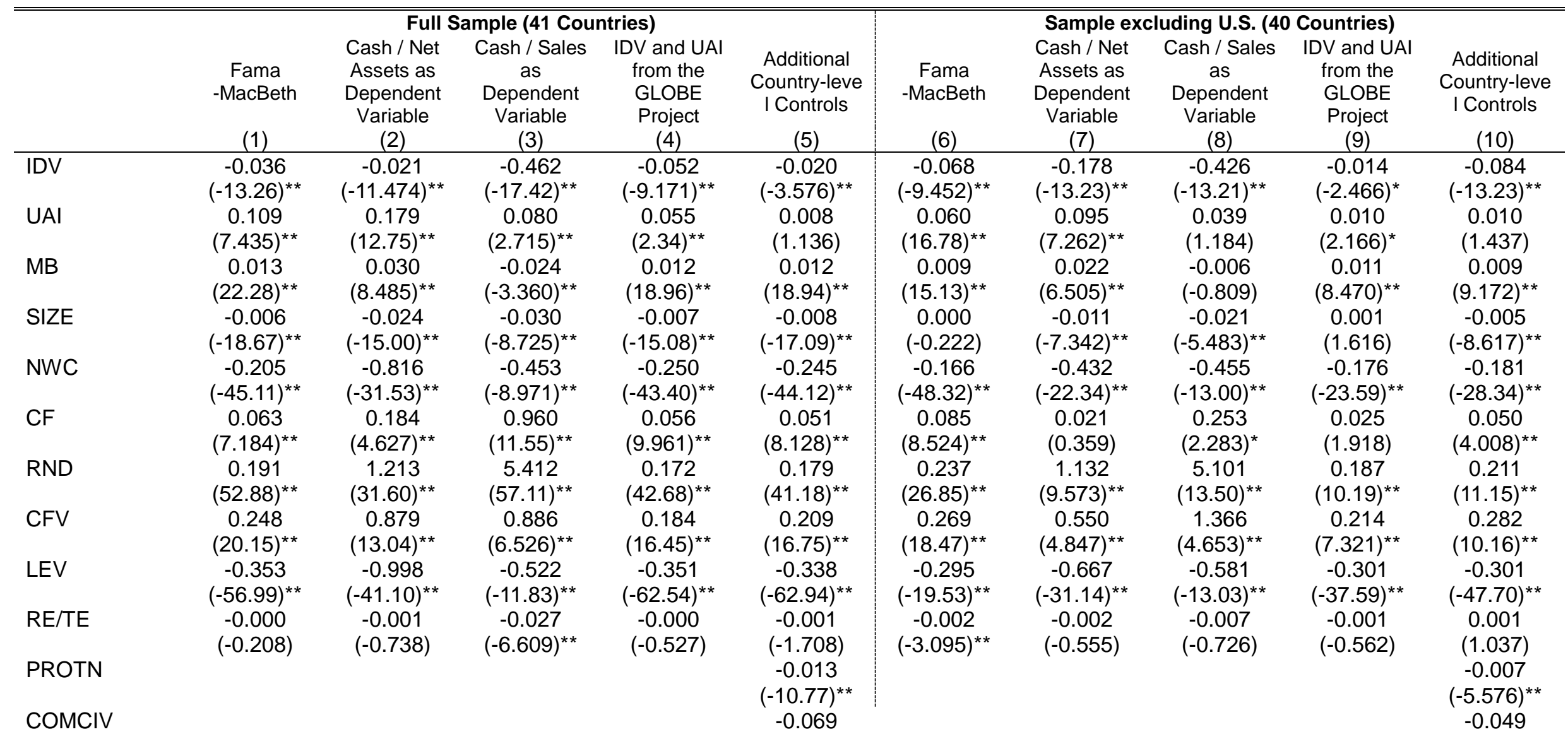




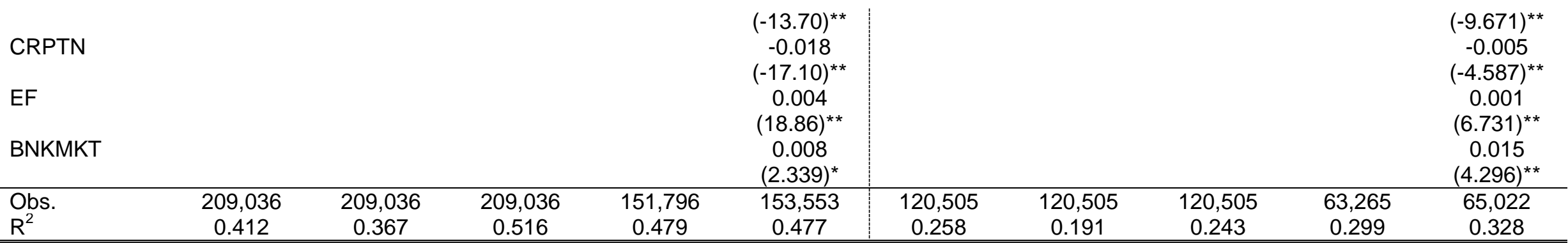

This table presents the regression results using the Fama-MacBeth method. The dependent variable is CASH, defined as cash and cash equivalents divided by book value of assets. IDV is Hofstede's individualism index and UAI is Hofstede's uncertainty avoidance index. MB is defined as market value of assets divided by book value of assets. Size is the natural logarithm of book value of assets. NWC is defined as working capital net of cash and cash equivalents divided by book value of assets. CF is defined as operating cash flow divided by book value of assets. RND is research and development expenses divided by sales revenue. CFV is defined as the standard deviation of CF for the previous 10 years, requiring at least three observations. LEV is defined as the book value of debt divided by book value of assets. RE/TE is defined as retained earnings as a proportion of total equity and is our main proxy for the life-cycle theory. PROTN is the investor protection index from LLSV (1998). COMCIV is a dummy variable equal to one if the country has common law origin and zero if it has civil law origin. CRPTN is the corruption index developed by Transparency International. EF is the economic freedom index developed by the Heritage Foundation. BNKMKT is a dummy variable equal to one if the country is a bank-based financial system and zero if it has a market-based financial system. All the regressions except Fama-MacBeth include industry fixed-effect, defined at the two-digit SIC code level. Regressions in Columns (1) and (6) are performed using Fama-MacBeth, and those in the other columns are performed using pooled OLS, with t-statistics (in parentheses) computed using standard errors robust to both clustering at the firm level and heteroskedasticity. Columns (1)-(5) present the results for the full sample (41 countries) and Columns (6)-(10) presents the results for the sample excluding the U.S. For ease of interpretation, we scale up the coefficients of the original IDV and UAI in Columns (1)-(3), (5)-(8) and (10) by multiplying the coefficients by $100 .{ }^{*}$ and ${ }^{* *}$ denotes significance at the $5 \%$, and $1 \%$ level respectively. 
TABLE 5

Regressions of Capital Investments, Acquisitions, Payout Policy and Repurchases on National Culture Sample Period: 1989-2009

CAPE / ACQ / DIV / REP $P_{i, t}=\alpha+\beta_{1} \cdot I D V_{i, t}+\beta_{2} \cdot U A I_{i, t}+\gamma \cdot$ Controls $_{i, t}+$ Ind $_{j, t}+Y r_{t}+\varepsilon_{i, t}$

\begin{tabular}{|c|c|c|c|c|c|c|c|c|}
\hline & \multicolumn{4}{|c|}{ Full Sample (41 Countries) } & \multicolumn{4}{|c|}{ Sample excluding U.S. (40 Countries) } \\
\hline & $(1)$ & (2) & (3) & $(4)$ & $(5)$ & (6) & (7) & $(8)$ \\
\hline & CAPE & $A C Q$ & DIV & REP & CAPE & $A C Q$ & DIV & REP \\
\hline \multirow[t]{2}{*}{ IDV } & 0.011 & 0.034 & -0.004 & 0.022 & 0.013 & 0.020 & -0.015 & 0.003 \\
\hline & $(8.576)^{* *}$ & $(51.46)^{\star *}$ & $(-5.288)^{\star *}$ & $(42.40)^{\star *}$ & $(7.924)^{\star *}$ & $(25.16)^{\star *}$ & $(-16.01)^{* *}$ & $(14.68)^{\star *}$ \\
\hline \multirow[t]{2}{*}{ UAI } & -0.039 & -0.018 & -0.016 & -0.011 & -0.039 & -0.009 & -0.014 & -0.002 \\
\hline & $(-25.97)^{\star *}$ & $(-27.89)^{\star \star}$ & $(-20.30)^{\star *}$ & $(-24.99)^{\star \star}$ & $(-24.16)^{\star \star}$ & $(-14.34)^{* *}$ & $(-16.49)^{\star *}$ & $(-13.22)^{\star *}$ \\
\hline \multirow[t]{2}{*}{ MB } & 0.002 & 0.000 & 0.002 & 0.001 & 0.002 & 0.000 & 0.003 & 0.000 \\
\hline & $(16.10)^{\star \star}$ & $(-2.961)^{\star \star}$ & $(17.69)^{\star \star}$ & $(11.18)^{\star \star}$ & $(9.854)^{\star *}$ & $(2.409)^{*}$ & $(17.49)^{\star *}$ & (1.914) \\
\hline \multirow[t]{2}{*}{ SIZE } & -0.001 & 0.001 & 0.000 & 0.001 & 0.000 & 0.000 & -0.001 & 0.000 \\
\hline & $(-5.935)^{\star *}$ & $(15.17)^{\star \star}$ & $(2.570)^{*}$ & $(19.20)^{\star *}$ & $(-0.705)$ & $(3.436)^{\star \star}$ & $(-6.427)^{\star *}$ & $(4.583)^{\star \star}$ \\
\hline \multirow[t]{2}{*}{ NWC } & -0.015 & 0.004 & -0.001 & -0.003 & -0.015 & 0.000 & 0.001 & 0.000 \\
\hline & $(-9.946)^{* *}$ & $(5.310)^{\star *}$ & $(-1.010)$ & $(-6.383)^{* *}$ & $(-7.677)^{\star *}$ & $(0.049)$ & $(0.674)$ & $(-2.276)^{*}$ \\
\hline \multirow[t]{2}{*}{ CF } & 0.011 & 0.010 & -0.002 & 0.009 & 0.045 & 0.009 & 0.013 & 0.001 \\
\hline & $(7.263)^{\star \star}$ & $(12.37)^{\star \star}$ & $(-2.650)^{\star *}$ & $(15.85)^{\star \star}$ & $(13.07)^{\star \star}$ & $(7.318)^{\star \star}$ & $(5.303)^{\star \star}$ & $(2.842)^{\star *}$ \\
\hline \multirow[t]{2}{*}{ RND } & -0.005 & -0.002 & -0.006 & -0.001 & -0.006 & 0.000 & -0.013 & 0.000 \\
\hline & $(-6.410)^{\star *}$ & $(-6.269)^{\star *}$ & $(-21.31)^{\star *}$ & $(-4.407)^{\star \star}$ & $(-3.029)^{\star *}$ & $(-0.136)$ & $(-11.63)^{\star *}$ & $(0.486)$ \\
\hline \multirow[t]{2}{*}{ CFV } & -0.001 & 0.002 & -0.035 & 0.004 & 0.024 & -0.004 & -0.023 & 0.003 \\
\hline & $(-0.159)$ & $(0.765)$ & $(-29.53)^{\star *}$ & $(3.900)^{* \star}$ & $(2.738)^{\star *}$ & $(-1.097)$ & $(-6.401)^{\star *}$ & $(3.030)^{\star *}$ \\
\hline \multirow[t]{2}{*}{ LEV } & 0.014 & 0.023 & -0.022 & -0.005 & 0.022 & 0.011 & -0.029 & 0.000 \\
\hline & $(8.987)^{\star *}$ & $(26.62)^{\star *}$ & $(-37.07)^{\star *}$ & $(-11.80)^{\star *}$ & $(10.68)^{\star *}$ & $(14.96)^{\star *}$ & $(-30.78)^{* *}$ & $(-2.020)^{*}$ \\
\hline \multirow[t]{2}{*}{$\mathrm{RE} / \mathrm{TE}$} & 0.001 & 0.000 & 0.001 & 0.000 & 0.001 & 0.000 & 0.001 & 0.000 \\
\hline & $(9.256)^{\star *}$ & $(2.053)^{\star}$ & $(26.75)^{\star \star}$ & $(8.445)^{\star \star}$ & $(4.059)^{\star \star}$ & $(-1.916)$ & $(13.92)^{\star *}$ & (1.812) \\
\hline Obs. & 209,036 & 209,036 & 209,036 & 209,036 & 120,505 & 120,505 & 120,505 & 120,505 \\
\hline Adj. $R^{2}$ & 0.192 & 0.074 & 0.140 & 0.087 & 0.189 & 0.054 & 0.231 & 0.020 \\
\hline
\end{tabular}


This table presents the regression results of capital investments, acquisitions, payout policy and repurchases on national culture (proxied by individualism and uncertainty avoidance) for the 40 countries in our sample. The dependent variables are CAPE, ACQ, DIV and REP, respectively. CAPE is defined as capital expenditure scaled by assets. ACQ is defined as acquisition expenditure scaled by assets. DIV is dividend payments scaled by assets. REP is repurchases expenditure scaled by assets. IDV is Hofstede's individualism index and UAI is Hofstede's uncertainty avoidance index. MB is defined as market value of assets divided by book value of assets. Size is the natural logarithm of book value of assets. NWC is defined as working capital net of cash and cash equivalents divided by book value of assets. CF is defined as operating cash flow divided by book value of assets. RND is research and development expenses divided by sales revenue. CFV is defined as the standard deviation of CF for the previous 10 years, requiring at least three observations. LEV is defined as the book value of debt divided by book value of assets. RE/TE is defined as retained earnings as a proportion of total equity and is our main proxy for the life-cycle theory. All regressions include industry fixed-effect, defined at the two-digit SIC code level, and year fixed-effect. We run pooled OLS regressions, with t-statistics (in parentheses) computed using standard errors robust to both clustering at the firm level and heteroskedasticity. The full sample results (41 countries) are reported in Columns (1) - (4) and the results for the sample excluding the U.S. are reported in columns (5) - (8). . For ease of interpretation, we scale up the coefficients of IDV and UAl by multiplying the coefficients by $100 .{ }^{*}$ and ${ }^{* *}$ denotes significance at the $5 \%$, and $1 \%$ level respectively. 
TABLE 6

Summary Statistics of State-level Collectivism Index in the U.S.

Sample Period: 1989-2009

\begin{tabular}{|c|c|c|c|c|c|c|c|c|c|c|c|c|}
\hline Country & $\begin{array}{c}\text { \# of } \\
\text { Obs. } \\
(1)\end{array}$ & $\begin{array}{c}\text { \# of } \\
\text { Firms } \\
(2)\end{array}$ & $\begin{array}{c}\text { CASH } \\
(3)\end{array}$ & $\begin{array}{c}\text { CLTM } \\
(4)\end{array}$ & $\begin{array}{l}\text { MB } \\
(6)\end{array}$ & $\begin{array}{c}\text { SIZE } \\
(7)\end{array}$ & $\begin{array}{c}\text { NWC } \\
(8)\end{array}$ & $\begin{array}{l}\text { CF } \\
(9)\end{array}$ & $\begin{array}{l}\text { RND } \\
(10)\end{array}$ & $\begin{array}{l}\text { CFV } \\
(11)\end{array}$ & $\begin{array}{l}\text { LEV } \\
(12)\end{array}$ & $\begin{array}{c}\text { RE/TE } \\
\text { (13) }\end{array}$ \\
\hline Alabama & 459 & 44 & 0.056 & 57 & 1.354 & 5.160 & 0.144 & 0.027 & 0.000 & 0.061 & 0.199 & 0.555 \\
\hline Alaska & 38 & 3 & 0.031 & 48 & 1.210 & 6.469 & -0.006 & 0.004 & 0.000 & 0.057 & 0.556 & 0.084 \\
\hline Arizona & 1,286 & 165 & 0.112 & 49 & 1.490 & 4.375 & 0.046 & 0.016 & 0.000 & 0.091 & 0.177 & 0.052 \\
\hline Arkansas & 370 & 29 & 0.022 & 54 & 1.405 & 6.159 & 0.032 & 0.032 & 0.000 & 0.039 & 0.304 & 0.657 \\
\hline California & 15,577 & 2,083 & 0.261 & 60 & 1.762 & 4.458 & 0.043 & -0.004 & 0.086 & 0.119 & 0.063 & 0.000 \\
\hline Colorado & 2,528 & 375 & 0.100 & 36 & 1.494 & 4.025 & -0.001 & -0.005 & 0.000 & 0.094 & 0.181 & 0.000 \\
\hline Connecticut & 2,103 & 247 & 0.073 & 50 & 1.462 & 5.085 & 0.096 & 0.020 & 0.008 & 0.069 & 0.230 & 0.188 \\
\hline Delaware & 274 & 31 & 0.086 & 55 & 1.366 & 4.872 & 0.028 & 0.010 & 0.006 & 0.052 & 0.237 & 0.364 \\
\hline Florida & 4,215 & 567 & 0.071 & 54 & 1.417 & 4.124 & 0.080 & 0.011 & 0.000 & 0.091 & 0.216 & 0.123 \\
\hline Georgia & 2,465 & 301 & 0.071 & 60 & 1.477 & 5.143 & 0.058 & 0.017 & 0.000 & 0.077 & 0.233 & 0.246 \\
\hline Hawaii & 128 & 11 & 0.051 & 91 & 1.276 & 4.338 & 0.003 & 0.005 & 0.000 & 0.100 & 0.183 & 0.881 \\
\hline Idaho & 196 & 24 & 0.100 & 42 & 1.385 & 5.858 & 0.053 & 0.011 & 0.000 & 0.111 & 0.183 & 0.298 \\
\hline Illinois & 3,611 & 401 & 0.053 & 52 & 1.457 & 5.563 & 0.106 & 0.026 & 0.000 & 0.048 & 0.233 & 0.406 \\
\hline Indiana & 863 & 93 & 0.054 & 57 & 1.248 & 5.174 & 0.150 & 0.033 & 0.000 & 0.060 & 0.203 & 0.501 \\
\hline lowa & 416 & 39 & 0.047 & 39 & 1.428 & 5.398 & 0.099 & 0.040 & 0.000 & 0.057 & 0.206 & 0.762 \\
\hline Kansas & 517 & 62 & 0.047 & 38 & 1.275 & 4.870 & 0.043 & 0.020 & 0.000 & 0.064 & 0.209 & 0.336 \\
\hline Kentucky & 427 & 38 & 0.043 & 53 & 1.247 & 5.754 & 0.118 & 0.033 & 0.000 & 0.040 & 0.263 & 0.445 \\
\hline Louisiana & 526 & 60 & 0.031 & 72 & 1.308 & 5.490 & 0.029 & 0.020 & 0.000 & 0.068 & 0.284 & 0.294 \\
\hline Maine & 86 & 9 & 0.293 & 45 & 1.645 & 3.566 & 0.125 & 0.051 & 0.068 & 0.056 & 0.052 & 0.110 \\
\hline Maryland & 1,514 & 195 & 0.141 & 63 & 1.592 & 4.196 & 0.045 & 0.001 & 0.018 & 0.086 & 0.146 & 0.000 \\
\hline Massachusetts & 5,371 & 602 & 0.268 & 46 & 1.714 & 4.438 & 0.062 & 0.004 & 0.079 & 0.103 & 0.061 & 0.012 \\
\hline Michigan & 1,611 & 161 & 0.051 & 46 & 1.320 & 5.054 & 0.114 & 0.024 & 0.004 & 0.063 & 0.206 & 0.492 \\
\hline Minnesota & 3,090 & 328 & 0.129 & 41 & 1.614 & 4.055 & 0.118 & 0.030 & 0.023 & 0.079 & 0.110 & 0.269 \\
\hline Mississippi & 219 & 27 & 0.040 & 64 & 1.301 & 5.365 & 0.048 & 0.018 & 0.000 & 0.078 & 0.344 & 0.534 \\
\hline
\end{tabular}




\begin{tabular}{|c|c|c|c|c|c|c|c|c|c|c|c|c|}
\hline Missouri & 1,260 & 129 & 0.039 & 46 & 1.474 & 5.876 & 0.115 & 0.036 & 0.000 & 0.045 & 0.248 & 0.541 \\
\hline Montana & 68 & 10 & 0.149 & 31 & 1.697 & 5.004 & 0.050 & 0.011 & 0.000 & 0.074 & 0.065 & 0.036 \\
\hline Nebraska & 299 & 29 & 0.055 & 35 & 1.585 & 5.555 & 0.081 & 0.035 & 0.000 & 0.039 & 0.203 & 0.593 \\
\hline Nevada & 744 & 99 & 0.118 & 52 & 1.468 & 4.768 & -0.025 & 0.005 & 0.000 & 0.071 & 0.330 & 0.129 \\
\hline New Hampshire & 395 & 47 & 0.114 & 43 & 1.583 & 4.521 & 0.117 & 0.029 & 0.033 & 0.077 & 0.157 & 0.173 \\
\hline New Jersey & 4,286 & 507 & 0.115 & 59 & 1.566 & 3.994 & 0.066 & 0.004 & 0.011 & 0.092 & 0.162 & 0.131 \\
\hline New Mexico & 114 & 19 & 0.086 & 51 & 1.521 & 3.006 & 0.077 & 0.006 & 0.000 & 0.107 & 0.307 & 0.000 \\
\hline New York & 7,451 & 982 & 0.095 & 53 & 1.388 & 4.443 & 0.088 & 0.012 & 0.000 & 0.070 & 0.182 & 0.245 \\
\hline North Carolina & 1,524 & 175 & 0.063 & 56 & 1.356 & 5.269 & 0.116 & 0.023 & 0.000 & 0.059 & 0.232 & 0.342 \\
\hline North Dakota & 31 & 4 & 0.056 & 37 & 1.039 & 2.543 & -0.015 & 0.020 & 0.000 & 0.112 & 0.220 & 0.781 \\
\hline Ohio & 2,909 & 276 & 0.037 & 45 & 1.322 & 5.793 & 0.137 & 0.030 & 0.000 & 0.049 & 0.245 & 0.546 \\
\hline Oklahoma & 768 & 111 & 0.033 & 42 & 1.398 & 4.305 & 0.011 & 0.025 & 0.000 & 0.076 & 0.269 & 0.280 \\
\hline Oregon & 918 & 96 & 0.112 & 33 & 1.421 & 4.606 & 0.122 & 0.025 & 0.009 & 0.079 & 0.143 & 0.238 \\
\hline Pennsylvania & 3,590 & 395 & 0.076 & 52 & 1.477 & 5.132 & 0.101 & 0.024 & 0.005 & 0.055 & 0.192 & 0.450 \\
\hline Rhode Island & 250 & 31 & 0.124 & 48 & 1.690 & 5.075 & 0.149 & 0.037 & 0.015 & 0.056 & 0.149 & 0.553 \\
\hline South Carolina & 401 & 50 & 0.025 & 70 & 1.332 & 5.104 & 0.139 & 0.033 & 0.000 & 0.055 & 0.217 & 0.578 \\
\hline South Dakota & 85 & 8 & 0.043 & 36 & 1.616 & 4.826 & 0.204 & 0.056 & 0.004 & 0.043 & 0.158 & 0.750 \\
\hline Tennessee & 1,275 & 138 & 0.044 & 56 & 1.448 & 5.667 & 0.047 & 0.037 & 0.000 & 0.047 & 0.287 & 0.345 \\
\hline Texas & 8,406 & 1,013 & 0.058 & 58 & 1.382 & 5.168 & 0.035 & 0.020 & 0.000 & 0.069 & 0.230 & 0.221 \\
\hline Utah & 729 & 97 & 0.134 & 61 & 1.739 & 3.712 & 0.067 & 0.013 & 0.015 & 0.120 & 0.157 & 0.150 \\
\hline Vermont & 109 & 11 & 0.070 & 42 & 1.483 & 3.337 & 0.119 & 0.027 & 0.000 & 0.077 & 0.244 & 0.191 \\
\hline Virginia & 2,068 & 255 & 0.067 & 60 & 1.404 & 5.125 & 0.080 & 0.019 & 0.000 & 0.065 & 0.201 & 0.407 \\
\hline Washington & 1,613 & 208 & 0.241 & 37 & 1.707 & 4.746 & 0.009 & -0.011 & 0.038 & 0.091 & 0.061 & 0.044 \\
\hline West Virginia & 102 & 12 & 0.071 & 48 & 1.055 & 4.602 & 0.004 & 0.030 & 0.000 & 0.057 & 0.248 & 0.222 \\
\hline Wisconsin & 1,221 & 109 & 0.039 & 46 & 1.373 & 5.520 & 0.156 & 0.035 & 0.009 & 0.039 & 0.196 & 0.694 \\
\hline Wyoming & 25 & 7 & 0.013 & 35 & 1.008 & 4.287 & -0.044 & -0.023 & 0.000 & 0.104 & 0.314 & 0.000 \\
\hline Total & 88,531 & 10,690 & 0.099 & 54 & 1.491 & 4.760 & 0.069 & 0.017 & 0.000 & 0.074 & 0.173 & 0.214 \\
\hline
\end{tabular}


This table reports the summary statistics for the 50 states in the U.S. for the period 1989 to 2009 . We obtain the state-level individualism-collectivism data from Vandello and Cohen (1999). We obtain financial information from Compustat North America. All numbers with the exception of number of observations and firms are state or sample medians. CASH is defined as cash and cash equivalents divided by book value of assets. MB is defined as market value of assets divided by book value of assets. Size is the natural logarithm of book value of assets. NWC is defined as working capital net of cash and cash equivalents divided by book value of assets. CF is defined as operating cash flow divided by book value of assets. RND is defined as research and development expenses divided by sales revenue. CFV is defined as the standard deviation of CF for the previous 10 years, requiring at least three observations. LEV is defined as the book value of debt divided by book value of assets. RE/TE is defined as retained earnings as a proportion of total equity and is our main proxy for the life-cycle theory. 
TABLE 7

Regressions of Cash Holdings on the State-level Individualism-collectivism dimension in the U.S.

Sample Period: 1989-2009

$$
\text { CASH }_{i, t}=\alpha+\beta \cdot I D V_{\text {STATE }, t}+\gamma \cdot \text { Controls }_{i, t}+\text { Ind }_{j, t}+Y_{t}+\varepsilon_{i, t}
$$

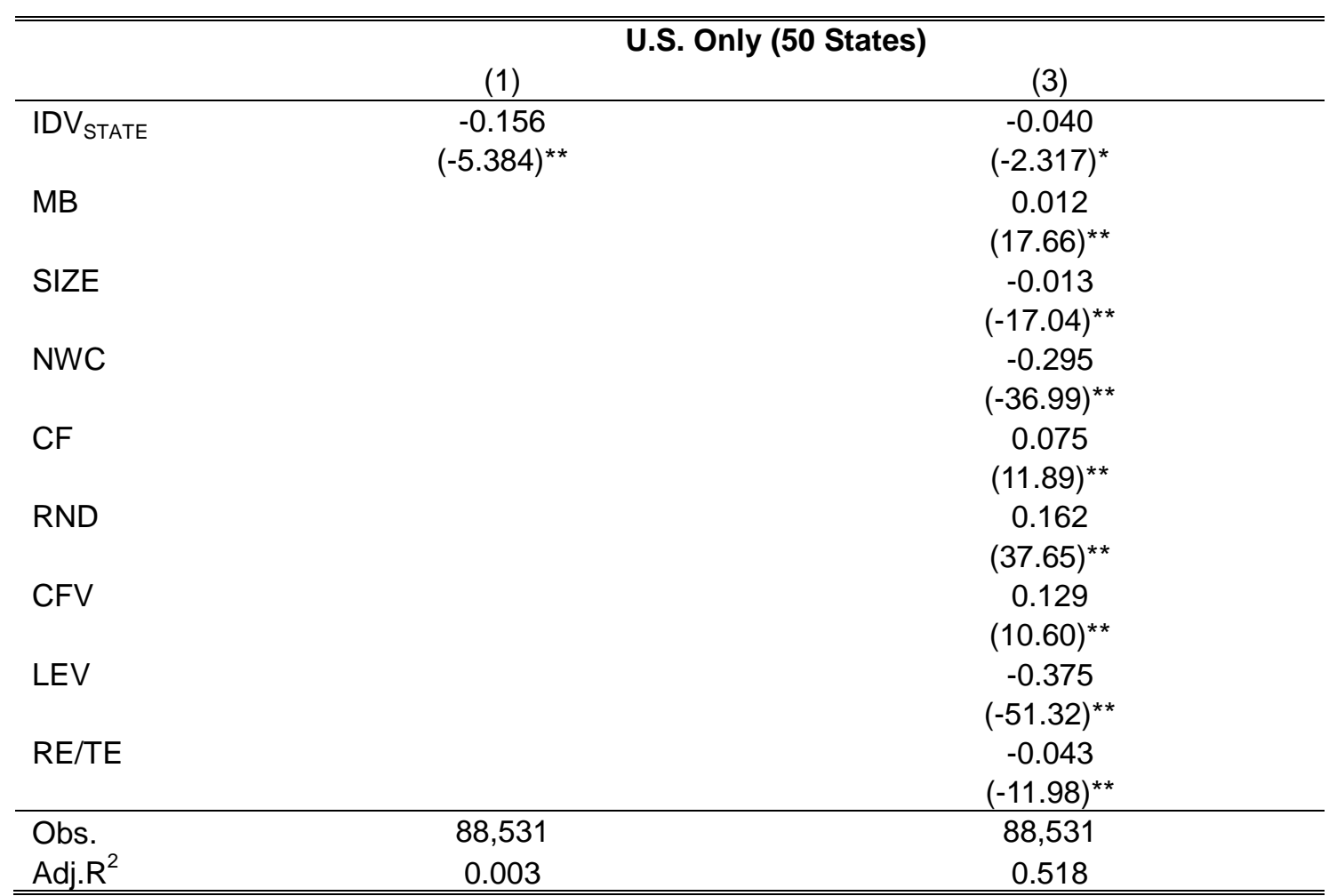

This table presents the regression results of cash holdings on regional culture in the U.S. (proxied by the Collectivism Index of Vandello and Cohen (1999)).The dependent variable is $\mathrm{CASH}$, defined as cash and cash equivalents divided by book value of assets. IDV $V_{\text {STATE }}$ is the state level collectivism index multiplied by -1 . MB is defined as market value of assets divided by book value of assets. Size is the natural logarithm of book value of assets. NWC is defined as working capital net of cash and cash equivalents divided by book value of assets. CF is defined as operating cash flow divided by book value of assets and RND is defined as research and development expenses divided by sales revenue. CFV is defined as the standard deviation of $\mathrm{CF}$ for the previous 10 years, requiring at least three observations. LEV is defined as the book value of debt divided by book value of assets. RE/TE is defined as retained earnings as a proportion of total equity and is our main proxy for the life-cycle theory. The regression includes industry fixed-effect, defined at the two-digit SIC code level, and year fixed-effect. We run pooled OLS regressions, with t-statistics (in parentheses) computed using standard errors robust to both clustering at the firm level and heteroskedasticity. For ease of interpretation, we scale up the coefficients of IDV and ${ }^{* *}$ denotes significance at the $5 \%$, and $1 \%$ level respectively. 
TABLE 8

Regressions of Capital Investments, Acquisitions, Payout Policy and Repurchases on the state level Individualism-collectivism dimension of Vandello and Cohen (1999) Sample Period: 1989-2009

$$
\begin{aligned}
& \text { CAPE / ACQ / DIV / REP } i, t=\alpha+\beta_{1} \cdot I D V_{\text {STATEi,t }}+\gamma_{1} \cdot S G R T H_{i, t}+\gamma_{2} \cdot N W C_{i, t} \\
& +\gamma_{3} \cdot B L E V_{i, t}+\gamma_{4} \cdot \operatorname{PROF}_{i, t}+\gamma_{5} \cdot S I Z E_{i, t}+I_{j, t}+Y r_{t}+\varepsilon_{i, t}
\end{aligned}
$$

\begin{tabular}{|c|c|c|c|c|}
\hline & \multicolumn{4}{|c|}{ U.S. Only (50 States) } \\
\hline & (1) & (2) & (3) & $(4)$ \\
\hline & CAPE & ACQ & DIV & REP \\
\hline \multirow[t]{2}{*}{ IDV $_{\text {STATE }}$} & 0.029 & 0.008 & 0.002 & 0.007 \\
\hline & $(4.680)^{\star *}$ & $(2.391)^{\star}$ & $(0.801)$ & $(3.800)^{\star *}$ \\
\hline \multirow[t]{2}{*}{ MB } & 0.003 & -0.001 & 0.001 & 0.001 \\
\hline & $(14.08)^{\star *}$ & $(-7.755)^{* *}$ & $(8.914)^{* *}$ & $(10.70)^{* *}$ \\
\hline \multirow[t]{2}{*}{ SIZE } & 0.001 & 0.003 & 0.002 & 0.002 \\
\hline & $(3.421)^{\star *}$ & $(16.97)^{\star *}$ & $(18.22)^{\star *}$ & $(18.96)^{* *}$ \\
\hline \multirow[t]{2}{*}{ NWC } & -0.022 & 0.002 & 0.003 & -0.008 \\
\hline & $(-9.942)^{\star *}$ & $(1.462)$ & $(3.433)^{* *}$ & $(-9.060)^{\star *}$ \\
\hline \multirow[t]{2}{*}{ CF } & -0.002 & 0.007 & -0.008 & 0.009 \\
\hline & $(-0.903)$ & $(7.043)^{\star \star}$ & $(-13.88)^{\star *}$ & $(12.72)^{\star *}$ \\
\hline \multirow[t]{2}{*}{ RND } & -0.004 & -0.002 & -0.004 & -0.002 \\
\hline & $(-4.738)^{\star *}$ & $(-4.655)^{* *}$ & $(-15.02)^{\star \star}$ & $(-7.353)^{\star *}$ \\
\hline \multirow[t]{2}{*}{ CFV } & -0.009 & -0.001 & -0.011 & -0.003 \\
\hline & $(-2.424)^{*}$ & $(-0.471)$ & $(-10.11)^{* *}$ & $(-2.610)^{\star *}$ \\
\hline \multirow[t]{2}{*}{ LEV } & -0.002 & 0.029 & -0.012 & -0.012 \\
\hline & $(-0.924)$ & $(19.96)^{\star *}$ & $(-17.51)^{\star \star}$ & $(-16.41)^{\star \star}$ \\
\hline \multirow[t]{2}{*}{ RE/TE } & 0.001 & 0.000 & 0.000 & 0.000 \\
\hline & $(7.098)^{\star *}$ & $(1.006)$ & $(15.57)^{\star *}$ & $(8.808)^{\star *}$ \\
\hline Obs. & 79,081 & 79,081 & 79,081 & 79,081 \\
\hline Adj. $R^{2}$ & 0.258 & 0.061 & 0.123 & 0.089 \\
\hline
\end{tabular}

This table presents the regression results of capital investments, acquisitions, payout policy and repurchases on regional culture in the U.S. (proxied by Individualism-Collectivism index of Vandello and Cohen 1999). The dependent variables are CAPE, ACQ, DIV and REP, respectively. CAPE is defined as capital expenditure scaled by assets. ACQ is defined as acquisition expenditure scaled by assets. DIV is dividend payments scaled by assets. REP is repurchases expenditure scaled by assets. IDV STATE is the state level collectivism index multiplied by -1 . MB is defined as market value of assets divided by book value of assets. Size is the natural logarithm of book value of assets. NWC is defined as working capital net of cash and cash equivalents divided by book value of assets. CF is defined as operating cash flow divided by book value of assets and RND is defined as research and development expenses divided by sales revenue. CFV is defined as the standard deviation of CF for the previous 10 years, requiring at least three observations. LEV is defined as the book value of debt divided by book value of assets. RE/TE is defined as retained earnings as a proportion of total equity and is our main proxy for the life-cycle theory. The regression includes industry fixed-effect, defined at the two-digit SIC code level, and year fixed-effect. We run pooled OLS regressions, with t-statistics (in parentheses) computed using standard errors robust to both clustering at the firm level and heteroskedasticity. For ease of interpretation, we scale up the coefficients of IDV $V_{\text {STATE }}$ by multiplying the coefficient by $100 .{ }^{*}$ and ${ }^{* *}$ denotes significance at the $5 \%$, and $1 \%$ level respectively. 
Figure 1

Plot of Individualism and Uncertainty Avoidance Index

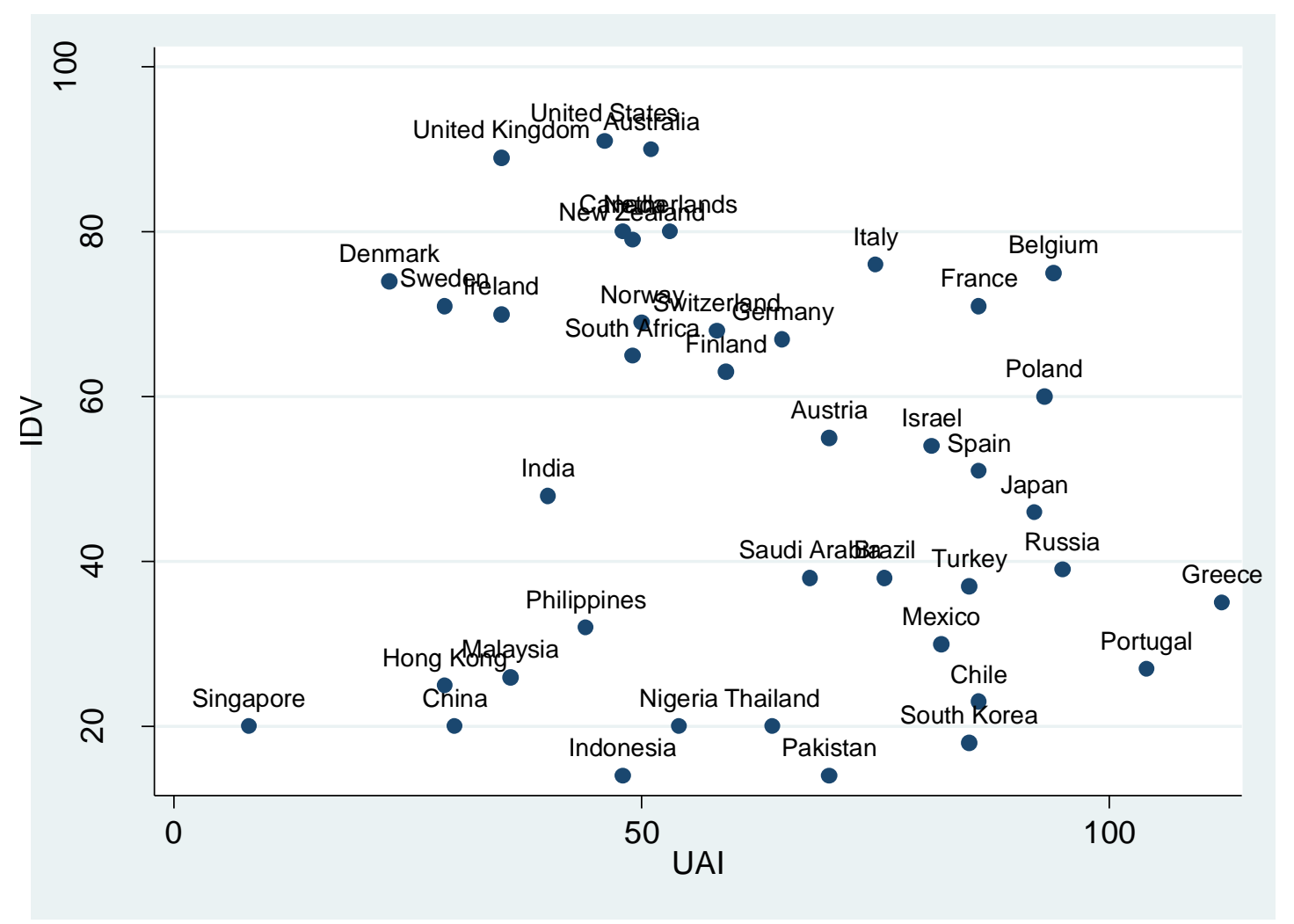

Figure 1 represents a country's score from the Hofstede's cultural dimensions survey. The vertical axis indicates the country's degree of individualism (IDV) versus collectivism and the horizontal axis indicates the society's tolerance for uncertainty and ambiguity (UAI). A high IDV ranking indicates that the society has more individualistic attitudes and loose bonds with others. That is, in individualistic societies everyone is expected to look after him/herself and his/her immediate family whereas in the collectivistic side societies are integrated into strong cohesive in-groups. Uncertainty Avoidance (UAI) deals with a society's tolerance for uncertainty and ambiguity. Uncertainty avoiding cultures try to minimize the possibility of unstructured situations by strict laws and rules, safety and security measures. Uncertainty accepting cultures, on the other hand, are more tolerant of opinions different from what they are used to and they try to have as few rules as possible. 
Figure 2

Culture-level Value Structure (Adapted from Schwartz (1994))

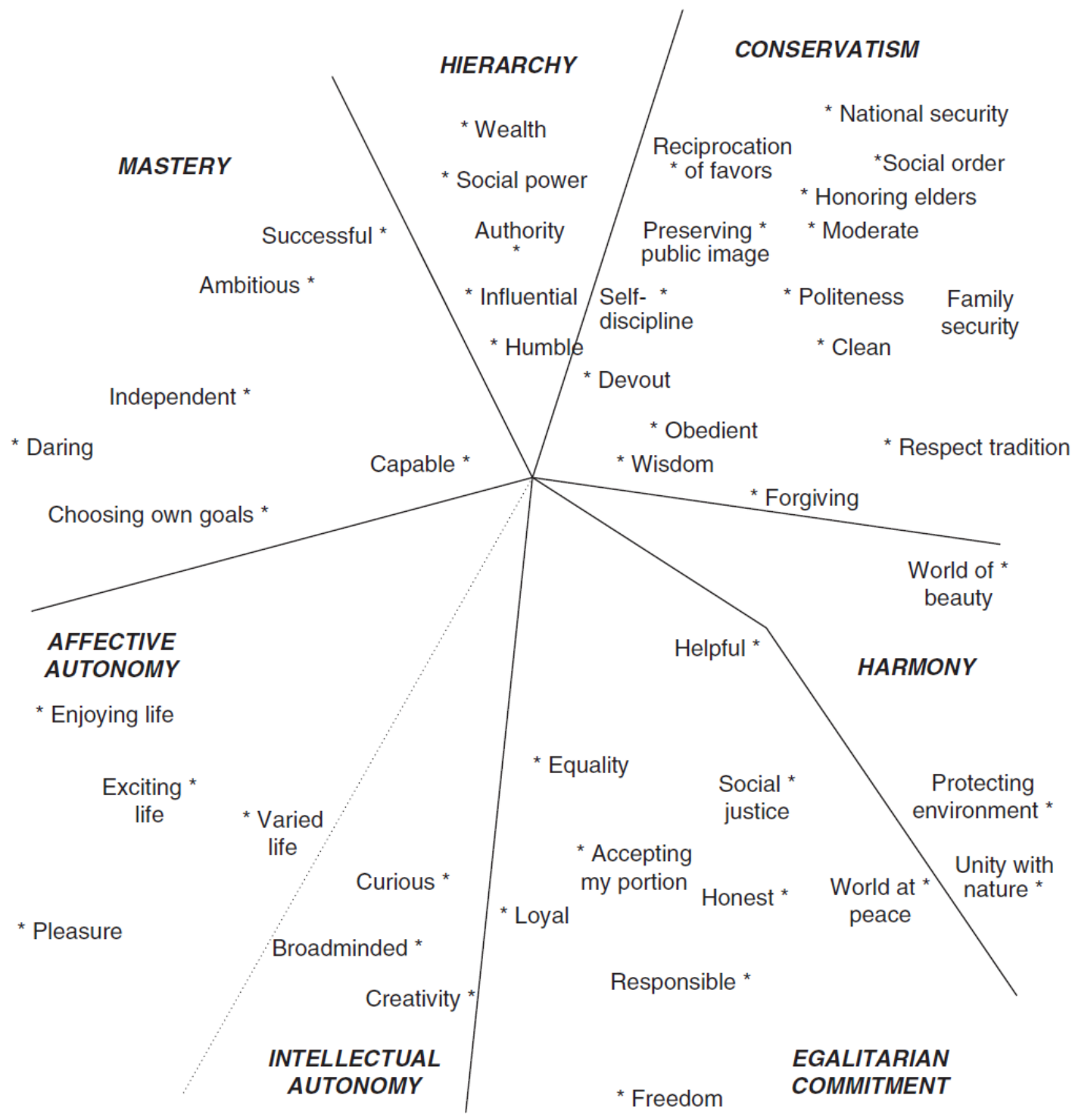

